\title{
Response of organophosphatic brachiopods to the mid-Ludfordian (late Silurian) carbon isotope excursion and associated extinction events in the Prague Basin (Czech Republic)
}

\author{
Michal Mergl, JiŘí FrÝda \& Michal Kubajko
}

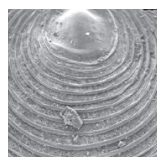

\begin{abstract}
The present paper represents the first results of an on-going multidisciplinary study focused on the response of marine faunas to the mid-Ludfordian (late Silurian) carbon isotope excursion and associated extinction events (Ludfordian, late Silurian). The paper describes the stratigraphical distribution of organophosphatic brachiopods from the uppermost part of the Neocucullograptus inexpectatus to lower part of Monograptus parultimus graptolite biozones (i.e. early Ludfordian to earliest Př́dolí). Numerical analysis of the stratigraphical distribution, based on more than 1300 determinable valves of 15 organophosphatic brachiopod species, revealed three groups being significantly supported. They are here formalized as new organophosphatic brachiopod communities: the oldest Opsiconidion ephemerus Community, the Kosoidea fissurella Community, and the youngest Opsiconidion parephemerus-Kosagittella clara Community. The Opsiconidion ephemerus Community and the Opsiconidion parephemerus-Kosagittella clara Community have distinct similarities in their taxonomic composition, moderate species diversity and low dominance indices. The communities are separated by the monospecific Kosoidea fissurella Community present just after the Lau and Kozlowskii bioevents during the period of high $\delta^{13} \mathrm{C}$ values which is interpreted as an opportunistic community. Re-occurrence of some brachiopod taxa after the bioevents and the mid-Ludfordian carbon isotope excursion raises the question, at least for organophosphatic brachiopods, as to the extent to which the Lau and Kozlowskii bioevents represent true global extinction events and whether their significance has not been overestimated. Two new species are erected: Opsiconidion bouceki and Opsiconidion parephemerus. • Key words: mid-Ludfordian carbon isotope excursion, Lau and Kozlowskii bioevents, Silurian, organophosphatic brachiopods, Barrandian, new taxa.
\end{abstract}

\begin{abstract}
Mergl, M., FrÝdA, J. \& KubajKo, M. 2018. Response of organophosphatic brachiopods to the mid-Ludfordian (late Silurian) carbon isotope excursion and associated extinction events in the Prague Basin (Czech Republic). Bulletin of Geosciences 93(3), 369-400 (11 figures, 2 tables). Czech Geological Survey, Prague. ISSN 1214-1119. Manuscript received April 15, 2018; accepted in revised form July 3, 2018; published online August 6, 2018; issued August 20, 2018.

Michal Mergl, Czech University of Life Sciences Prague, Faculty of Environmental Sciences, Department of Environmental Geosciences, Kamýcká 129, 165 00, Praha-Suchdol, Czech Republic; Argyrotheca@seznam.cz •Jiř́ Frýda, Czech University of Life Sciences Prague, Faculty of Environmental Sciences, Department of Environmental Geosciences, Kamýcká 129, 165 00, Praha - Suchdol, Czech Republic \& Czech Geological Survey, Klárov 3/131, 11821 Praha 1, Czech Republic • Michal Kubajko, Czech Geological Survey, Klárov 3/131, 11821 Praha 1, Czech Republic
\end{abstract}

The Silurian Period represents a rather unusual period in Earth history. During the last two decades several distinct and rapid changes in the Silurian global carbon cycle have been recognized. These geochemical events were closely linked to major crises in marine ecosystems as well as to palaeoclimatic changes (see Munnecke et al. 2003, Loydell 2007, Calner 2008, for reviews). The largest magnitude perturbation in the Silurian global carbon cycle, named the mid-Ludfordian carbon isotope excursion (CIE) by Kaljo et al. (1997), has been considered also to represent the largest carbon isotope excursion throughout the whole Phanerozoic and the second largest in Earth history
(Munnecke et al. 2003). On the other hand, the midLudfordian CIE was preceded only by moderate faunal crises referred to as the Lau conodont Bioevent (Jeppsson 1987), Kozlowskii graptolite Bioevent (Urbanek 1993), and Pentamerid Bioevent (Talent et al. 1993). The midLudfordian CIE and the associated faunal turnover have been documented from many palaeocontinents, in particular from different areas of Baltica (see Kaljo et al. 1996, 1997, 2007, 2014; Calner 2008; Eriksson et al. 2009; Jeppsson et al. 2012; Kozłowski \& Munnecke 2010; Kozłowski \& Sobień 2012; Younes et al. 2016; Spirodonov et al. 2017), Australia (Talent et al. 1993; 
Andrew et al. 1994; Jeppsson et al. 2007, 2012), Laurentia (Barrick et al. 2010), Perunica (Lehnert et al. 2003, 2007a, b; Manda et al. 2012; Frýda \& Manda 2013), Avalonia (Loydell \& Frýda 2011), and the Carnic Alps (Histon \& Schönlaub 1999, Brett et al. 2009, Histon 2012).

The high magnitude of the $\delta^{13} \mathrm{C}$ values has led to the mid-Ludfordian carbon isotope excursion probably being one of the most intensively studied of all Palaeozoic geochemical events. However, the vast majority of studies have focused on geochemical aspects of the midLudfordian CIE whilst the associated bioevents (i.e. Lau conodont Bioevent, Kozlowskii graptolite Bioevent, and Pentamerid Bioevent) are still poorly known. During the last two decades only a few studies (Stricanne et al. 2006, Tonarová et al. 2012, Spirodonov et al. 2017) have analysed the response of biota to the mid-Ludfordian geochemical perturbation.

In this paper we present new data on the stratigraphical distribution of organophosphatic brachiopods across the mid-Ludfordian CIE and analyse their taxonomic composition. Another goal of the present study is to evaluate the response of organophosphatic brachiopods to the mid-Ludfordian CIE and associated extinction events.

\section{Geological settings and previous studies}

Only a small part of the Palaeozoic Prague Basin is preserved and this is sometimes referred to as the Prague Synform (Fig. 1). The basin is a younger component of the Proterozoic crustal block called the Barrandian (or Teplá-Barrandian terrane). The facies distribution of Silurian strata indicates that shallow water domains were surrounded by deeper and open marine settings dominated by hemi-pelagic deposition. Whether the Barrandian formed part of the accreted peri-Gondwanan terranes (Stampfli et al. 2002) or was a small isolated crustal block (microcontinent or terrane) often referred to as Perunica (Havlíček et al. 1994, Cocks \& Torsvik 2002) is still a matter of discussion (e.g. Žák \& Sláma 2018). Nevertheless, the latter seems to be the more likely scenario as the Silurian faunas of the Barrandian show a distinct affinity to both peri-Gondwanan as well as BalticAvalonian-Laurentian faunas, indicating that Perunica was located in the temperate zone (Krríž 1999, 2008; Manda 2008; Ebbestad et al. 2013). The diverse movements of the tectonic blocks within the Prague Basin as well as global sea level fluctuations gave rise to a high number of varied biotopes which were inhabited by specific faunal communities (Havlíček \& Štorch 1990, 1999; Kříž 1998b, 1999) and produced a rather complicated facies pattern. Detailed descriptions of middle and late Ludfordian strata in the Barrandian were published by Kříž $(1992,1998$ a) and Manda \& Kř́ž (2006).

The organophosphatic brachiopods described in the present paper come from Kosov section JF195 (Frýda \& Manda 2013) located in the area of the Silurian Kosov Volcanic Centre where intense volcanic activity continued from the latest Wenlock up to the late Gorstian (Fig. 1; Kř́̌ž 1991, 1992, 1998a; Tasáryová et al. 2018). As shown by Kř́ž (1992), synsedimentary movements and accumulations of volcanic products gave rise to a topographic high on the seafloor with preservation of relatively shallow water sedimentary deposits that persisted from the latest Wenlock up to the early Přídolí (Bouček 1934, Bouček \& Přibyl 1955, Horný 1955, Křriž 1992). A latest Wenlock-early Ludlow volcano-sedimentary succession is overlain by limestone-dominated successions of mid and late Ludlow (Ludfordian) age. Evidence for volcanic activity manifested by the occurrence of thin beds of tuffites preserved within Ludfordian strata probably represent volcanic material originating from an area outside the Kosov Volcanic Centre.

Kosov section JF195 is situated in the Kosov Quarry and encompasses the middle and upper parts of the Kopanina Formation and lowermost part of the overlying Požáry Formation. The lithology of the Ludfordian strata in Kosov Quarry has been described by many researchers (Bouček 1934, Bouček \& Přibyl 1955, Horný 1955, Křriž 1992, Manda \& Kř́ž 2006). A lithological description of the studied section was provided by Gocke et al. (2013) and Frýda \& Manda (2013).

Kosov Quarry provides many well exposed sections through the whole Wenlock and Ludlow and has been an area for many biostratigraphical and palaeontological studies (see summary in Havlíček \& Štorch 1990, 1999; Kř́žz 1987, 1992, 1998b, 1999). Present knowledge of distribution of the biota as well as of faunal communities in the studied Kosov section (JF195) is in Frýda \& Manda (2013). The section provides one of the most complete mid-Ludfordian carbon isotope excursion records in the world (Lehnert et al. 2007a, Frýda \& Manda 2013). This is one of the reasons why some new geochemical studies of the mid-Ludfordian CIE have used samples from this limestone succession (Farkaš et al. 2016, 2017; Frýda \& Frýdová 2017).

Figure 1. Distribution of Silurian rocks in the Barrandian (Perunica) including the position of the studied sections (A) and Silurian synsedimentary tectonics, volcanic and tectonic elevations, and segments (sub-basins) in the preserved parts of the Prague Basin (B; after Kř́ž 1991). Schematic drawing of Kosov section no. JF195 with basic data on lithology and biostratigraphy showing the stratigraphical distribution of organophosphatic brachiopod species. 


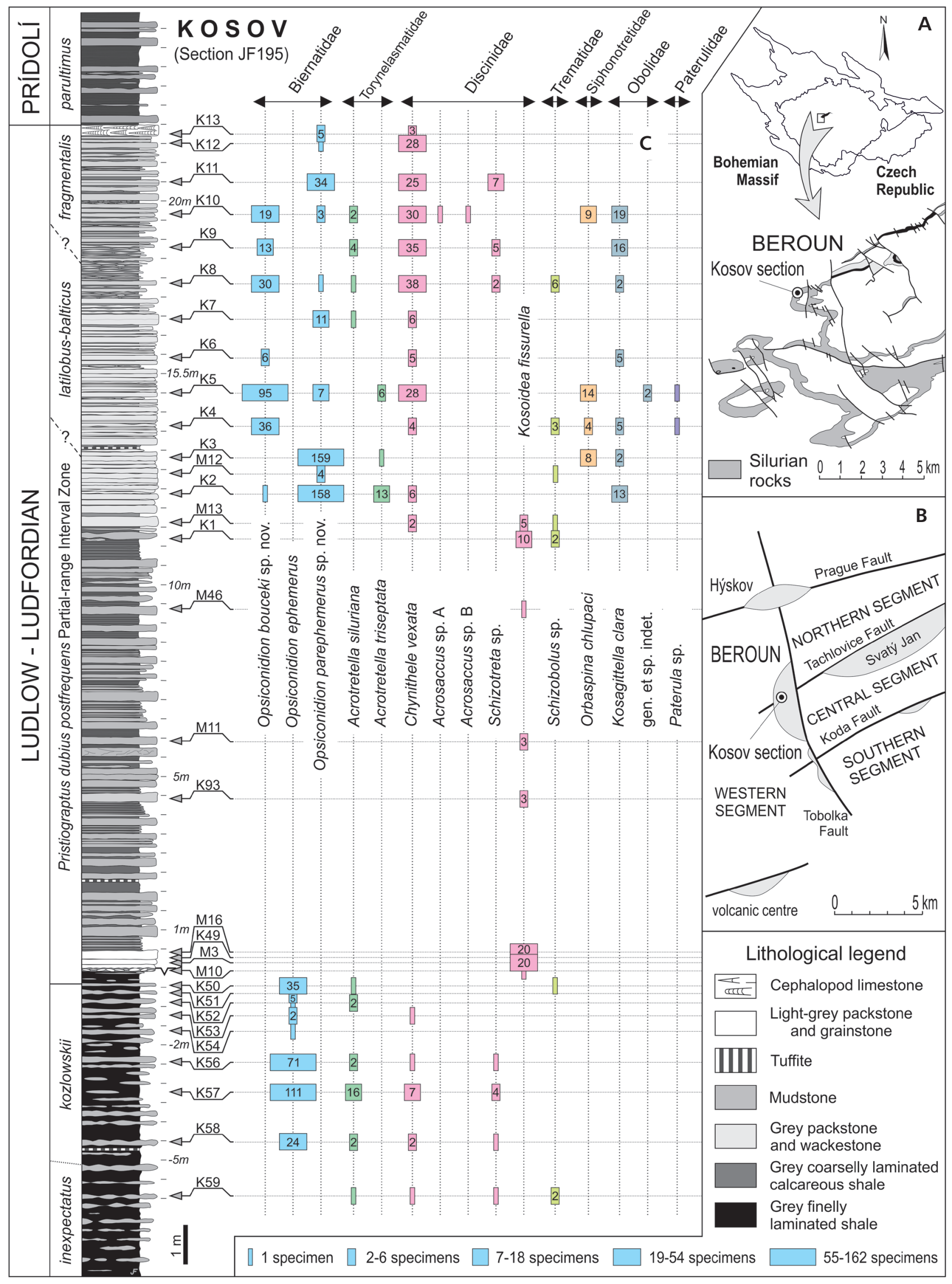




\section{Sampling and methods}

The organophosphatic brachiopods described in this paper come from more than 40 conodont samples collected from Kosov section JF195 in 2016 from the stratigraphical interval from the uppermost part of the Neocucullograptus inexpectatus to lower part of the Monograptus parultimus graptolite biozones (lower Ludfordian to the lowermost Prídolí; Fig. 1C). The limestone samples yielded conodonts, scolecodonts, chitinozoans, prasinophytes, acritarchs, organophosphatic brachiopods, sometimes accompanied also by sponge spicules, crinoid columnals, ostracods, juvenile gastropods and bivalves, mazuelloids, hyoliths, graptoloids, palaeoscolecids, conulariids, microvertebrates and unidentifiable organic fragments. The organophosphatic brachiopods were found in 31 conodont samples.

The initial bulk samples varied in weight from 1 to $2 \mathrm{~kg}$. They were treated with $6 \%$ acetic acid. After dissolution the residue was gently rinsed through 80,50 and $10 \mu \mathrm{m}$ sieve. Finally, the wet samples were handpicked from Petri dishes under a stereomicroscope, using a micropipette or an eyelash. The specimens are stored in small plastic containers filled with glycerine and a drop of formaldehyde to prevent mould growth.

The specimens were photographed using a Scanning Electron Microscope (SEM JEOL 6300) at the Biology Centre of the Academy of Sciences of the Czech Republic in České Budějovice. In each sample all determinable valves of organophosphatic brachiopods were counted, ventral and dorsal valves separately. The number of specimens of each species in each sample was inferred from the number of the more common valve (i.e. dorsal or ventral). New data on the stratigraphical distribution of the organophosphatic brachiopods described in this paper were evaluated by basic statistical methods.

Documentary material on Kosov section JF195 including all fossil groups from the above-mentioned samples is housed in the collection of Jiři Frýda, Czech Geological Survey (Prague), under the numbers JF195_1-95.

\section{Results}

Taxonomic evaluation of the organophosphatic brachiopods from Kosov section JF195 reveals the presence of 15 species (see Systematic palaeontology, p. xxx) belonging to the families Obolidae King, 1846 (Kosagittella clara Mergl, 2001a, gen. et sp. indet.); Paterulidae Cooper, 1956 (Paterula sp.); Biernatidae Holmer, 1989 [Opsiconidion ephemerus (Mergl, 1982), Opsiconidion bouceki sp. nov., and Opsiconidion parephemerus sp. nov.]; Torynelasmatidae Rowell, 1965 (Acrotretella siluriana
Ireland, 1961, and Acrotretella triseptata Mergl, 2001a); Discinidae Gray, 1840 [Acrosaccus sp. A, Acrosaccus sp. B, Chynithele vexata (Barrande, 1879), Kosoidea fissurella Havlíček \& Mergl, 1988, Schizotreta sp.]; Trematidae Schuchert, 1893 (Schizobolus sp.) and Siphonotretidae Kutorga, 1848 (Orbaspina chlupaci Mergl, 2003).

About 2000 valves of organophosphatic brachiopods were determined to species level from the 31 samples studied and more than 1300 records of organophosphatic brachiopods were used for numerical evaluation of their stratigraphical distribution using above-mentioned approach [i.e. number of individuals equals number of the more common valve (i.e. dorsal or ventral)]. The relative abundance of the organophosphatic brachiopod valves as well as the taxonomic composition of samples varied considerably among the samples (Fig. 1C). The high difference in numbers of individuals in the samples complicates statistical evaluation of their diversity and stratigraphical distribution. Therefore, the robustness of the samples was tested by rarefaction analysis which suggests that the sampling of organophosphatic brachiopods in some samples was not sufficient (due to the small number of individuals in some samples). However, it is difficult to improve robustness by additional sampling because of the rarity of some species (Fig. 1C). Nevertheless, the present dataset shows a contrasting pattern in the stratigraphical distribution of the organophosphatic brachiopods.

Species diversity shows a distinct pattern with the lowest diversity in the middle part of the section (Fig. 1C; Tab. 1). Judging from the statistically more robust samples there is moderate species diversity in the lower part of the section (i.e. from sample K59 to K50) seemingly with a trend towards lower diversity. Dominance varies (Tab. 2) from about 0.75 initially and seems to have slightly increasing trend although this has low statistical support. The interval from sample M10 to M46 is characterized by the occurrence of one species (Kosoidea fissurella) only and therefore the diversity in this interval is the lowest and the dominance inevitably the highest (i.e. 1). In the upper part of the section, between samples K1 and K13, species diversity increases significantly reaching its maximum in the samples K10 (8 species; see Fig. 1C, Tab. 1) and the dominance index decreases significantly to 0.25 .

Cluster analysis was used to analyse similarities between samples (Fig. 2). Because of the low robustness of some samples, we applied two simple approaches: cluster analysis of binary data (absence-presence) for stratigraphical distribution of species (i) and genera (ii) using the DICE similarity index (Fig. 2). The cluster analysis revealed an almost identical topology of dendrograms even though the dendrogram is better supported for the species dataset (cophenetic correlation coefficient is about 0.8 compared with 0.65 for the generic dataset). The analysis divided data into three 
Similarity

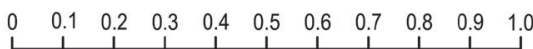

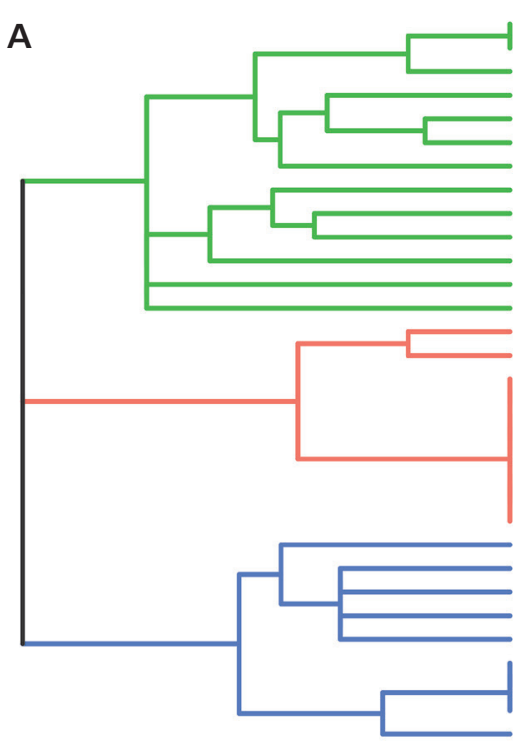

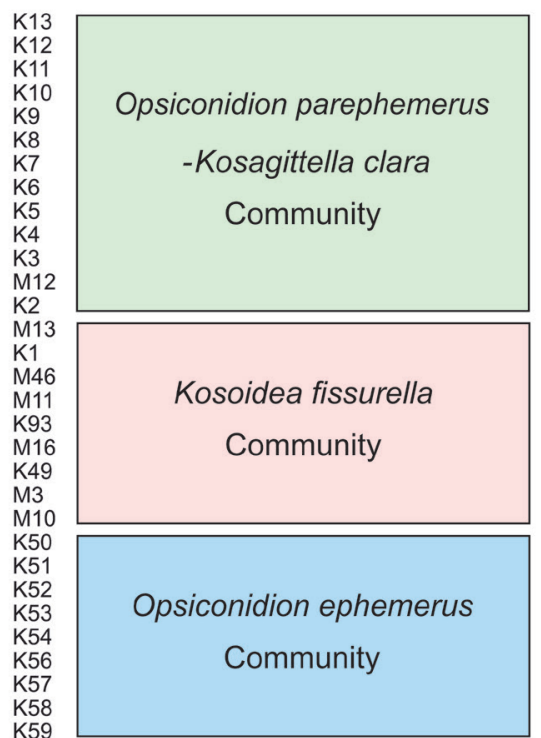

Similarity

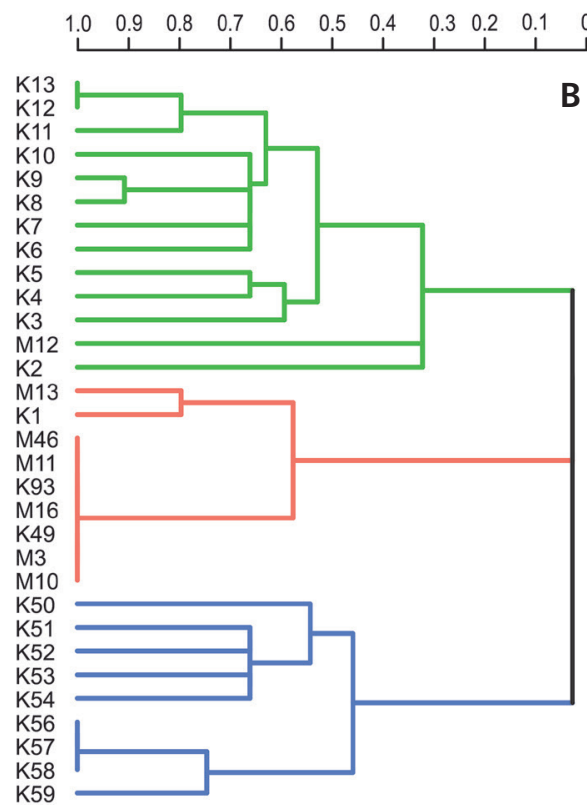

Figure 2. Dendrograms from cluster analysis of the stratigraphical distribution of brachiopod (A) species and (B) genera and names of newly established organophosphatic brachiopod communities.

Table 1. Taxonomic distribution of organophosphatic brachiopods in the newly established communities.

\begin{tabular}{|c|c|c|c|c|c|c|}
\hline \multirow[b]{2}{*}{ Species } & \multicolumn{2}{|c|}{$\begin{array}{c}\text { Opsiconidion ephemerus } \\
\text { Community }\end{array}$} & \multicolumn{2}{|c|}{$\begin{array}{l}\text { Kosoidea fissurella } \\
\text { Community }\end{array}$} & \multicolumn{2}{|c|}{$\begin{array}{c}\text { Opsiconidion parephemerus- } \\
\text { Kosagittella clara } \\
\text { Community }\end{array}$} \\
\hline & $\begin{array}{l}\text { number of } \\
\text { specimens }\end{array}$ & $\%$ & $\begin{array}{l}\text { number of } \\
\text { specimens }\end{array}$ & $\%$ & $\begin{array}{l}\text { number of } \\
\text { specimens }\end{array}$ & $\%$ \\
\hline Opsiconidion ephemerus & 250 & 84.5 & 0 & 0 & 0 & 0 \\
\hline Opsiconidion bouceki sp. nov. & 0 & 0 & 0 & 0 & 200 & 21.3 \\
\hline Opsiconidion parephemerus sp. nov. & 0 & 0 & 0 & 0 & 383 & 40.9 \\
\hline Acrotretella siluriana & 24 & 8.1 & 0 & 0 & 8 & 0.9 \\
\hline Acrotretella triseptata & 0 & 0 & 0 & 0 & 20 & 2.1 \\
\hline Chynithele vexata & 12 & 4.1 & 2 & 2.7 & 208 & 22.2 \\
\hline Acrosaccus sp. A & 0 & 0 & 0 & 0 & 1 & 0.1 \\
\hline Acrosaccus sp. B & 0 & 0 & 0 & 0 & 1 & 0.1 \\
\hline Schizotreta sp. & 7 & 2.4 & 0 & 0 & 14 & 1.5 \\
\hline Kosoidea fissurella & 0 & 0 & 69 & 93.2 & 0 & 0 \\
\hline Schizobolus sp. & 3 & 1.0 & 3 & 4.1 & 10 & 1.1 \\
\hline Orbaspina chlupaci & 0 & 0 & 0 & 0 & 35 & 3.7 \\
\hline Kosagittella clara & 0 & 0 & 0 & 0 & 53 & 5.7 \\
\hline gen. et sp. indet. & 0 & 0 & 0 & 0 & 2 & 0.2 \\
\hline Paterula sp. & 0 & 0 & 0 & 0 & 2 & 0.2 \\
\hline Total number of specimens & 296 & $100 \%$ & 74 & $100 \%$ & 937 & $100 \%$ \\
\hline
\end{tabular}

distinct groups which are interpreted and defined here as organophosphatic brachiopod communities (Fig. 2).

The first community is the Opsiconidion ephemerus Community (new name), characterized by the dominance of Opsiconidion ephemerus and Acrotretella siluriana
(Tab. 1). The community occurs only in the lower part of the studied section (Fig. 2). A monospecific community, the Kosoidea fissurella Community (new name), is restricted to the middle part of the section. The most diverse community, the Opsiconidion parephemerus- 
Table 2. Numerical data on samples of organophosphatic brachiopods.

\begin{tabular}{|c|c|c|c|c|}
\hline Community & Samples & Taxa & Individuals & Dominance \\
\hline \multirow{13}{*}{ 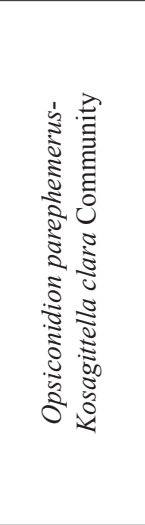 } & K13 & 2 & 8 & 0.53 \\
\hline & K12 & 2 & 29 & 0.93 \\
\hline & K11 & 3 & 66 & 0.42 \\
\hline & K10 & 8 & 75 & 0.26 \\
\hline & K9 & 5 & 73 & 0.32 \\
\hline & K8 & 7 & 80 & 0.37 \\
\hline & K7 & 3 & 18 & 0.49 \\
\hline & K6 & 3 & 16 & 0.34 \\
\hline & K5 & 7 & 153 & 0.43 \\
\hline & K4 & 6 & 53 & 0.49 \\
\hline & $\mathrm{K} 3$ & 4 & 170 & 0.88 \\
\hline & M12 & 2 & 5 & 0.68 \\
\hline & $\mathrm{K} 2$ & 5 & 191 & 0.69 \\
\hline \multirow{9}{*}{ 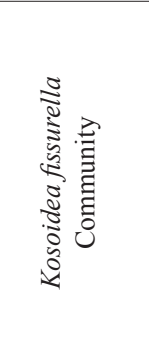 } & M13 & 3 & 8 & 0.47 \\
\hline & $\mathrm{K} 1$ & 2 & 12 & 0.72 \\
\hline & M46 & 1 & 1 & 1.00 \\
\hline & M11 & 1 & 3 & 1.00 \\
\hline & K93 & 1 & 3 & 1.00 \\
\hline & M16 & 1 & 20 & 1.00 \\
\hline & K49 & 1 & 6 & 1.00 \\
\hline & M3 & 1 & 20 & 1.00 \\
\hline & M10 & 1 & 1 & 1.00 \\
\hline \multirow{9}{*}{ 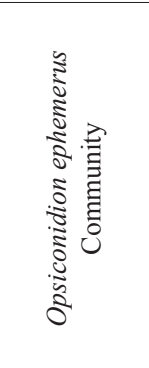 } & K50 & 3 & 37 & 0.90 \\
\hline & K51 & 1 & 5 & 1.00 \\
\hline & K52 & 2 & 3 & 0.56 \\
\hline & K53 & 2 & 3 & 0.56 \\
\hline & K54 & 1 & 1 & 1.00 \\
\hline & K56 & 4 & 75 & 0.90 \\
\hline & K57 & 4 & 138 & 0.66 \\
\hline & K58 & 4 & 29 & 0.70 \\
\hline & K59 & 4 & 5 & 0.28 \\
\hline
\end{tabular}

Kosagittella clara Community (new name), occurs in the upper part of the section. The last community is characterized by four dominant species, Opsiconidion parephemerus, Opsiconidion bouceki, Chynithele vexata and Kosagittella clara, and contains up to 8 species of the organophosphatic brachiopods (Tab. 1)

\section{Stratigraphical distribution of the brachiopods and their palaeoecology}

\section{Linguloidean brachiopods}

Two different obolid species, Kosagittella clara Mergl, 2001, and two specimens belonging to an indeterminable obolid genus, were recorded in the studied section (Fig. 1C, Tab. 1) but only the first species is a significant faunal component. Kosagittella clara occurs only in the upper part of the section (Fig. 1) as a typical element of the Opsiconidion parephemerus-Kosagittella clara Community. The micromorphic genus Kosagittella, having a distinctively shaped ventral pseudointerarea, is the most common obolid genus in several Ludlow to Eifelian limestone units of the Prague Basin. Obolid brachiopods are usually assumed to be sediment-dwelling animals (Emig 1997) although commensalism or endosymbiosis on corals (Tapanila \& Holmer 2006) or an epiplanktic mode of life have also been considered (Williams \& Lockley 1983). The majority of the Lower Palaeozoic obolids preferred infaunal mode of life in siliciclastic sediments, some in the deep basinal environment (Cherns 1979). Unlike to the larger parallel-sided obolids of Silurian age (e.g. Mergl 2001a, Cocks \& Popov 2009), the shell of Kosagittella is micromorphous, convex and therefore the animal was hardly infaunal. The environmental limits of Kosagittella are not well known, but its Devonian species in the Prague Basin are most abundant in shallow or moderately deep, oxic and assumed warm-water environments ( ̌reporyje, Chýnice, Suchomasty and Acanthopyge limestones; Pragian to Eifelian). The genus is rare in black limestones of hypoxic origin (Mergl 2001a, 2009; Mergl \& Ferrová 2009; Mergl \& Jiménez-Sánchez 2015).

\section{Discinoidean brachiopods}

Six discinoidean species, Schizobolus sp., Acrosaccus sp. A, Acrosaccus sp. B, Chynithele vexata, Schizotreta sp., and Kosoidea fissurella, were observed in the studied section (Fig. 1, Tab. 1). However, only the last three taxa are common. In comparison with the obolids, their stratigraphical distribution is more complex. Chynithele vexata which has subcircular valves and Schizotreta sp. with its elongately-oval outlined valves occur in the lower part as well as in the upper part of the studied section and demonstrate an unusual bimodal distribution. Both species are elements of the Opsiconidion ephemerus and Opsiconidion parephemerus-Kosagittella clara communities. The absence of Chynithele vexata in the middle part of the section, in the Kosoidea fissurella Community, is particularly remarkable because in total more than 220 determinable valves of this species were documented below and above strata bearing the Kosoidea fissurella Community (Figs 1,2). In contrast to that, Kosoidea fissurella, a discinoid with medium-sized and distinctly convexo-plane valves, occurs only in the middle part of the section where it is the only species. Kosoidea fissurella likely had special ecological requirements and could represent an opportunistic species (r-strategist). Two other discinoidean species, Acrosaccus sp. A and Acrosaccus sp. B, large and very rare brachiopods with convexo-conical valves, were found only in the Opsiconidion parephemerus-Kosagittella clara Community. 
The Silurian and Devonian discinoid brachiopods are usually the most common but also the most poorly known organophosphatic brachiopods. They are often referred to the genera Acrosaccus Willard, 1928, Orbiculoidea d'Orbigny, 1847 and Schizotreta Kutorga, 1848. Even though some discinoidean genera have cosmopolitan distributions, the small- to median-sized discinoideans were most common in warm to temperate climatic zones during the Ordovician (Cooper 1956) to the Devonian (Mergl 2001a; Valentine et al. 2003, 2006). On the other hand, large to very large discinoideans seems to be restricted to mild to cool climates and cold water environments since the Devonian (Boucot 1975, Boucot et al. 2001, Mergl \& Massa 2005) through to the Recent (Zezina 2008).

The discinoideans were generally epibenthic but as shown by Bassett et al. (2009) and Mergl (2010b), clustering on floating hard substrates (e.g. drifted cephalopod shells and weed tufts) was also a common life mode from the Ordovician onwards (Bassett et al. 2009, Mergl 2010a). The Kosoidea-like medium to large sized discinids, having planar ventral valves and low conical dorsal valves, have been documented from Palaeozoic cool water environments (Morris \& Sharpe 1846, Sharpe 1856, Reed 1925, Mendez-Alzola \& Sprechmann 1971, Boucot 1975, Boucot et al. 2001, Mergl \& Massa 2005). Today, large discinids are linked with the cold Humboldt Current (Zezina 2008, Montecino \& Lange 2009) and cold Benguela current (Hiller 1993) upwelling ecosystems. In the case of the Benguela system, Discinisca tenuis is moderately common in nearshore oxygenated water but is absent in the oxygen minimum zone. Its distribution indicates limited tolerance to hypoxic conditions (Zettler et al. 2009). The Late Ordovician Soom Shale from South Africa (Bassett et al. 2009) provided discinids having Kosoidea-like morphology attached to nektonic to necropelagic substrates that sank rapidly to a barren sea floor (Bassett et al. 2009). Bassett et al. (2009) noted that the anoxic bottom environment of the Soom Shale was transiently colonized by a few rhynchonelliformeans and discinid brachiopods during temporary oxic or only weakly hypoxic conditions. Taken together, in constrast to the small-sized discinids and acrotretoids, cool water conditions likely were an acceptable environment for the larger discinids. By analogy, this may explain the restricted occurrence of Kosoidea fissurella in a stratigraphical interval starting just after cooling and extinction events (Lehnert et al. 2007a, b; Frýda \& Manda 2013; Gocke et al. 2013).

\section{Acrotretid brachiopods}

Five species of acrotretid brachiopods belonging to the genera Opsiconidion Ludvigsen, 1974, and Acrotretella
Ireland, 1961 were documented from the Kosov section (Figs 1,2). Species of both genera are missing in the Kosoidea fissurella Community and there are elements of both the older Opsiconidion ephemerus as well as the younger Opsiconidion parephemerus-Kosagittella clara communities. However, unlike the discinoid Chynithele vexata, none of the acrotretid species occurs concurrently in both communities.

Opsiconidion is the commonest lingulate in the studied section, sometimes with more than 100 specimens in a sample. Three species, O. ephemerus (Mergl, 1982), $O$. parephemerus sp. nov., and $O$. bouceki sp. nov., were documented (Fig. 1). Of these, O. ephemerus occurs abundantly in limestone beds below the onset of the midLudfordian CIE. However, the stratigraphical range of this species is much longer because its first occurrence is in the lower part of the Kopanina Formation (Cromus beaumonti Horizon; early Ludfordian), within which this species is the most common organophosphatic brachiopod. Mergl (2001a) noted that the youngest Silurian occurrence of $O$. ephemerus is in the middle part of the Požáry Formation (mid-Př́ídolí). However, new taxonomic re-evaluation, based on newly collected material, has revealed that $O$. ephemerus disappeared just before the onset of the mid-Ludfordian carbon isotope excursion. Two additional species of Opsiconidion, O. bouceki sp. nov. and $O$. parephemerus sp. nov. outnumber the shells of other lingulates in the upper part of the section bearing the Opsiconidion parephemerus-Kosagittella clara Community (Figs 1A, 2; Tab. 1).

Opsiconidion is a long-ranging genus with its earliest occurrence in the Darriwilian (Sutton et al. 2000). From the Sandbian and Katian (Popov et al. 1994, Holmer \& Popov 2000) to the Middle Devonian, the genus is known from various carbonate rocks. It occurs in argillaceous limestone and marlstone (Popov et al. 1994) as well as in grey and red micritic limestone and coarse-grained limestone (Brock et al. 1995, Valentine et al. 2003). The main Late Ordovician and Silurian occurrences of the genus follow the temperate to tropical zones. The youngest known species are from late Eifelian and Givetian strata (O. decessus Mergl, 2001a; O. minor Popov, 1981).

The mode of life of Opsiconidion species is still a matter of discussion although it has been widely discussed (Cocks 1979, Bassett 1984, Mergl \& Vodrážková 2012). Opsiconidion could have been a microsized epiplanktic brachiopod drifting on floating substrates, but an epibenthic mode of life has also been discussed (Mergl \& Vodrážková 2012). Botting (2002) suggested that Opsiconidion occured only in relatively highly oxygenated environments and was intolerant to dysoxia and anoxia. According to Botting's model, Ordovician volcanic ashfall deposits in a shelf region of central Wales led to water overturning. This mixing of deep dysaerobic water with 
aerobic surface water enabled a bloom of small mobile benthos and upwelling of nutrients from deeper water. Botting (2002, p. 101) noted that the plankton bloom led to spreads of benthic populations of Opsiconidion nudum.

Species of the other acrotretid genus, Acrotretella, occurring in the Kosov section are not abundant. The more common species, Acrotretella siluriana Ireland, 1961, has the same bimodal stratigraphical distribution as Chynithele vexata, and belongs to both the Opsiconidion ephemerus and Opsiconidion parephemerus-Kosagittella clara communities. However, this species has a much longer stratigraphical distribution in the Prague Basin ranging from Llandovery to Ludlow. Our study provides the first evidence not only for the species Acrotretella siluriana but also for the genus Acrotretella in the Kopanina Formation (Ludlow). The second species of Acrotretella, A. triseptata, was found only in the upper part of the section (Opsiconidion parephemerusKosagittella clara Community). Acrotretella triseptata Mergl, 2001a has also been reported as a rare species in the Lower Devonian (Lochkovian) Lochkov Formation. Acrotretella spinosa Mergl, 2001a occurs in the upper part of the Požáry Formation (Přídolí).

Acrotretella Ireland, 1961, is another long-ranging genus. Its earliest occurrence was documented from the Dapingian (= ?Arenig) strata of Poland (Biernat \& Harper 1999). The genus is known mostly from temperate and tropic regions from the Upper Ordovician (Holmer 1986, 1989), Silurian (Ireland 1961, Satterfield \& Thompson 1969, Mergl 2001a, Valentine et al. 2003, Valentine 2006a) to Lower Devonian (Mergl 2001a, Valentine 2006a). Its morphology is highly conservative (Biernat \& Harper 1999). Taken together, the known palaeogeographical occurrences of Acrotretella species suggest its link to temperate or tropical climatic zones and to a moderate diversity of benthic associations.

\section{Siphonotretid brachiopods}

The only siphonotretid brachiopod, Orbaspina chlupa$c i$, occurs in the upper part of the section within the Opsiconidion parephemerus-Kosagittella clara Community. This species was based on ten dorsal valves coming from dark limestones of the Kopanina Formation (Ananaspis fecunda to Prionopeltis archiaci horizons) from Kosov Quarry (Mergl 2003).

The post-Ordovician siphonotretids are generally scarce and were recently revised by Valentine \& Brock (2003) and Valentine (2006b). At least two postOrdovician genera are known, the first an unnamed acanthambonine genus from the Wenlock of the Prague Basin (Mergl 2001a, b). The second unites "Siphonotreta" anglica (Morris, 1849) from Wales, and several so far unnamed species referred to Orbaspina Valentine \& Brock, 2003 coming from the upper Llandovery of New South Wales, Australia (Valentine \& Brock 2003), and Ludlow to Emsian of the Prague Basin (Mergl 2001a, 2003; Mergl \& Vodrážková 2012; Mergl \& JiménezSánchez 2015).

Siphonotretid brachiopods preferred argillitic to fine arenaceous substrates (Mergl et al. 2007). Their abundance rapidly decreases towards black shales biofacies indicating probably their sensitivity to hypoxic environments. Their evolutionary acme during the Furongian to Floian interval was followed by their rapid retreat in the Middle and Late Ordovician (Wright \& Clean 1991). The latest Ordovician siphonotretids are Multispinula drummuckensis Harper, 1984 from the Rawtheyan (upper Katian) of Scotland, and ?Acanthambonia sp. from the uppermost Katian of Bohemia (Mergl 2012), both of which are distinct from post-Ordovician siphonotretids. Apparently, the siphonotretids were highly affected by the spread of cool water at the beginning of the Hirnantian.

\section{Faunal communities and the $\delta^{13} \mathrm{C}$ record}

The upper part of the Kopanina Formation in the Kosov area has been investigated for its rich fossil record for almost two centuries since the classical work of Joachim Barrande. During recent decades biostratigraphers have defined several faunal communities which have been used for biostratigraphical correlation in this part of the Prague Basin (see Bouček 1934; Bouček \& Přibyl 1955; Horný 1955; Kř́iž 1992; Havlíček \& Štorch 1990, 1999, for summary). Correlation of the newly established organophosphatic brachiopod communities, namely i) the Opsiconidion ephemephus Community, ii) Kosoidea fissurella Community, and iii) Opsiconidion parephemerusKosagittella clara Community, is shown in Figure 3. The stratigraphical distribution of the organophosphatic brachiopod communities fits well with some of the earlier established faunal communities.

The Opsiconidion ephemerus Community ends in the limestone bed with the LAD of Polygnathus siluricus, thus at end of the $P$. siluricus conodont Biozone and slightly before the end of the Neocucullograptus kozlowskii graptolite Biozone. This level coincides roughly with the upper limit of the Diacanthaspis (A.) minuta trilobite Community (for a list of species see Havlíček \& Štorch 1990, 1999; Kř́íz 1992). The appearance of the Opsiconidion ephemerus Community is not well known (and is likely be below the lowest sample studied, see below), but this community ranges through the entire $N$. kozlowskii graptolite Biozone. The occurrence of Opsiconidion ephemerus in the lower part of the Kopanina Formation (Cromus beaumonti Horizon) 


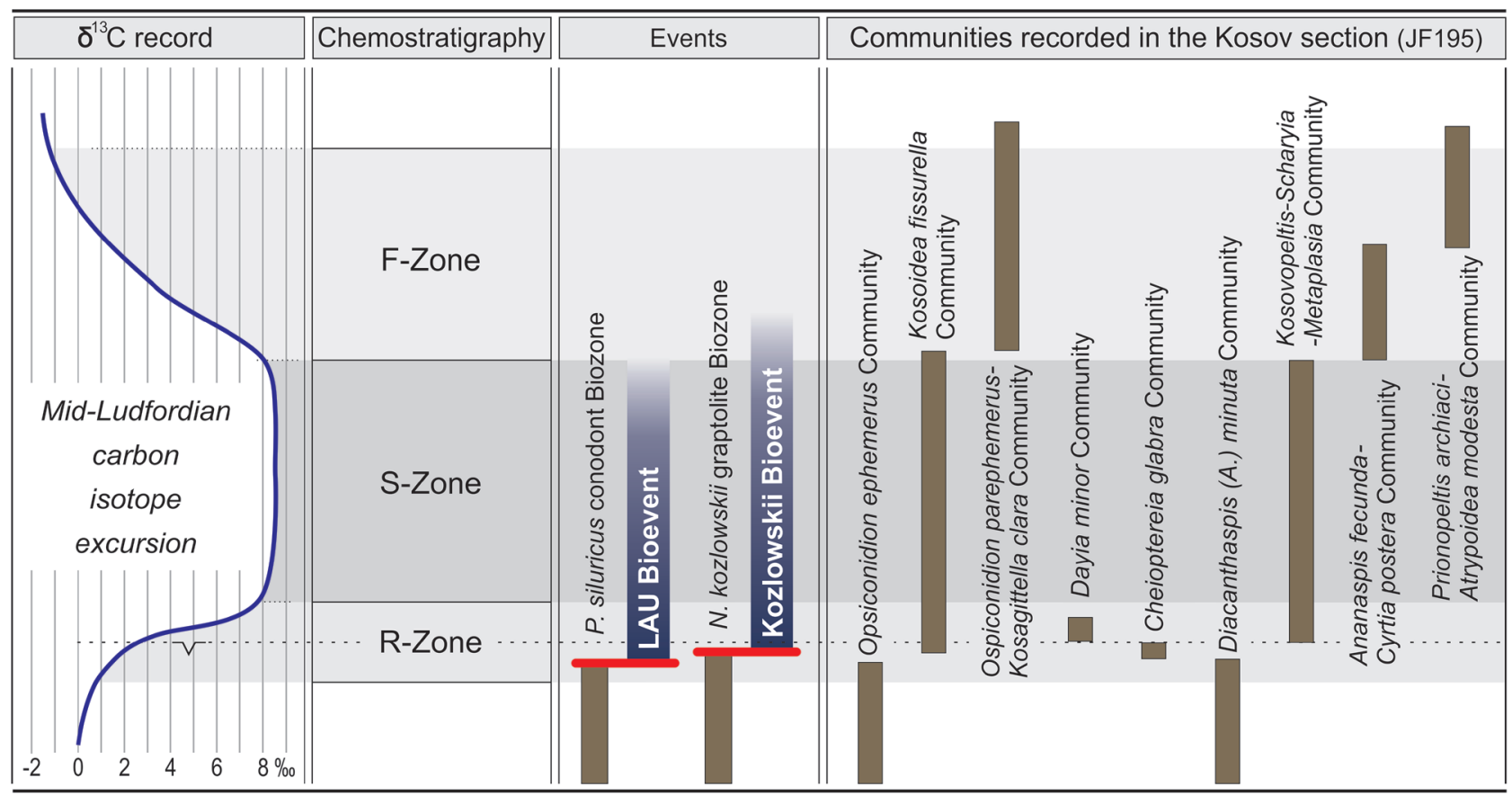

Figure 3. Diagram showing a stratigraphical correlation of the $\delta^{13} \mathrm{C}$ record, graptolite and conodont bioevents, and faunal communities recorded in Kosov section JF195 (based on Frýda \& Manda 2013).

suggests that the stratigraphical range of the Opsiconidion ephemerus Community could be much longer.

The stratigraphical range of the Kosoidea fissurella Community is very limited. It starts (based on the one valve in sample M10), just above the top of the $N$. kozlowskii graptolite Biozone, within the short-ranged Cheiropteria glabra bivalve Community. However, about $10 \mathrm{~cm}$ higher in limestone beds bearing the Dayia minor brachiopod Community (see Havlíček \& Štorch 1990, 1999; Kříž 1992), the abundance of Kosoidea fissurella is much higher and the Kosoidea fissurella Community continues across the entire stratigraphical range of the overlying Kosovopeltis-Scharyia-Metaplasia trilobite Community. The Kosoidea fissurella Community probably has a similar range as the Pristiograptus dubius postfrequens graptolite Partial-range Interval Zone (see Frýda \& Manda 2013). The LAD of the Kosoidea fissurella Community occurs in the limestone with the oldest occurrence of the Ananaspis fecunda-Cyrtia postera Community (Figs 1, 3; Tab. 1). The Opsiconidion parephemerus-Kosagittella clara Community ranges from the Ananaspis fecundaCyrtia postera Community into the overlying Prionopeltis archiaci-Atrypoidea modesta Community (Figs 1, 3; Tab. 1). Thus it probably appeared in the uppermost part of the Pristiograptus dubius postfrequens Biozone and is restricted to the upper Ludfordian corresponding to the Pseudomonoclimacis latilobus-Slovinograptus balticus and Pristiograptus fragmentalis graptolite biozones. The Opsiconidion parephemerus-Kosagittella clara
Community disappears just before the base of the Př́ídolí strata of the Požáry Formation (Fig. 1C).

It is noteworthy that stratigraphical range of the newly established organophosphatic brachiopod communities correlates well not only with the ranges of the other faunal communities and with lithological patterns but also with the dynamics of the mid-Ludfordian carbon isotope excursion (see Fig. 3).

\section{Response of organophosphatic brachiopods to environmental changes}

Our analysis of newly gathered data on organophosphatic brachiopods has revealed three distinct groups (Fig. 2) which are formally established here as new organophosphatic brachiopod communities. In addition, new taxonomic data demonstrate a similarity in generic composition between the oldest (Opsiconidion ephemerus Community) and the youngest (Opsiconidion parephemerus-Kosagittella clara Community) communities which are separated by the monospecific Kosoidea fissurella Community occurring just after the Lau and Kozlowskii bioevents during a period of high $\delta^{13} \mathrm{C}$ values. The Kosoidea fissurella Community is interpreted as an opportunistic community. The simplest explanation of the observed stratigraphical pattern is that the organophosphatic brachiopod faunal communities (Fig. 3) responded similarly to other faunal communities to the 


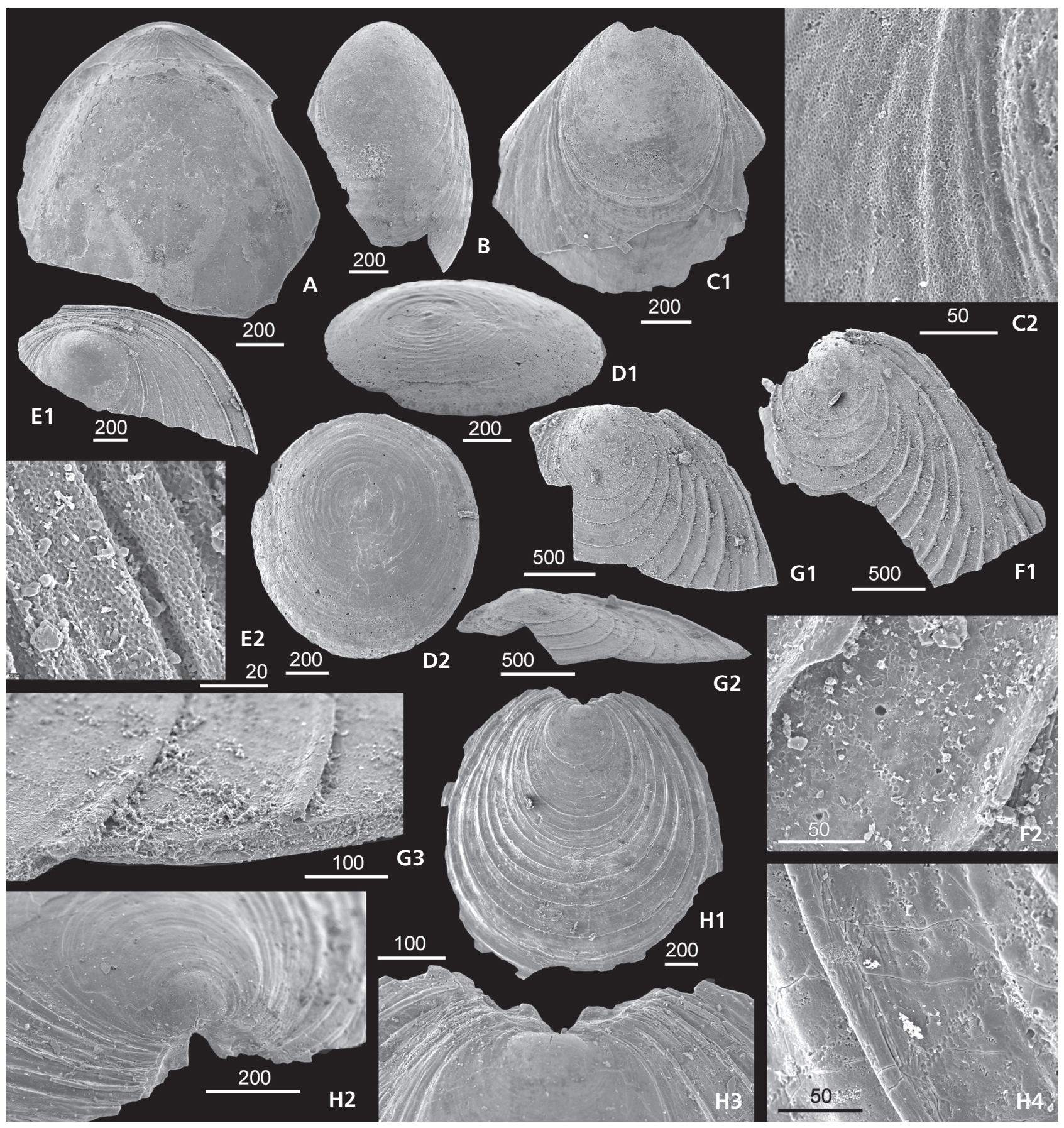

Figure 4. A-C - Kosagittella clara Mergl, 2001a, Kosov Quarry, sample K10 (all); A - interior of incomplete dorsal valve, JF195_1; B - exterior of incomplete ventral valve, JF195_2; C - exterior of ventral valve (1) and detail of pitted microornament near junction with the larval shell (2), JF195_3. • D - Paterula sp., Kosov Quarry, sample K25. Exterior of dorsal valve in oblique (1) and dorsal (2) views, JF195_87. E - Schizotreta sp., Kosov Quarry, sample K10. Exterior of incomplete dorsal valve (1) and detail of microornament (2), JF195_4.•F-H - Schizobolus sp., Kosov Quarry, samples K8 (F, G), M3 (H); F - exterior of incomplete dorsal valve (1) and detail of microornament (2), JF195_80; G - exterior of incomplete dorsal valve (1), the same in anterodorsal view (2), and detail of ornament (3), JF195_85; H - exterior of ventral valve (1), detail of pseudointerarea (2), apical view to shell posterior part (3) and detail of microornament (4), JF195_88. Length of bars in $\mu \mathrm{m}$.

environmental changes that caused the Lau and Kozlowskii bioevents.

Analysis of lithological pattern in Kosov section JF195 (Lehnert et al. 2007a, Frýda \& Manda 2013,
Gocke et al. 2013) has revealed that the onset of the midLudfordian carbon isotope anomaly is associated with rapid regression. This shallowing event has been recognized across the Prague Basin and caused a distinct 
stratigraphical gap in the NE as well as S parts of the basin (Manda \& Krríž 2006, Lehnert et al. 2007a, Manda et al. 2012, Gocke et al. 2013).

The bimodal stratigraphical distribution of some organophosphatic brachiopods (Acrotretella siluriana, Chynithele vexata, Schizotreta sp., and Schizobolus sp.), which occur before as well as after the mid-Ludfordian CIE, suggests that these species were not affected by the Lau and Kozlowskii extinction events, but only decreased their ecospace and lived in other areas during the postextinction (recovery) period and then returned back when environmental conditions ameliorated. This raises again the question as to how much the Lau and Kozlowskii bioevents represent real global extinction events or whether their significance has been overestimated. Sealevel drop at the onset of the mid-Ludfordian CIE was almost certainly climatically driven (Lehnert et al. 2007b) and caused environmental changes limiting the ecospace of some species which might, after the $\delta^{13} \mathrm{C}$ excursion, have returned back. The disappearance of such species may be wrongly interpreted as their extinction if data from only a short stratigraphical interval are available.

\section{Systematic palaeontology}

Phylum Brachiopoda, Duméril, 1806

Subphylum Linguliformea, Williams et al., 1996

Order Lingulida Waagen, 1885

Superfamily Linguloidea Menke, 1828

Family Obolidae King, 1846

\section{Genus Kosagittella Mergl, 2001a}

Type species. - By original designation, Kosagittella clara Mergl, 2001a from the Kopanina Formation (Ludfordian, Ludlow, Silurian) of the Prague Basin, Czech Republic.

\section{Kosagittella clara Mergl, 2001a}

Figure 4A-C

2001a Kosagitella clara; Mergl, p. 11, pl. 3, figs 1-12.

Material. -60 dorsal and 30 ventral valves, all incomplete; figured specimens: JF195_1-3.

Description. - See Mergl (2001a).

Remarks. - All available shells are extremely fragmentary and generally only the thickened posterior margin of valve is preserved. Despite this preservation, a larval shell, deep and short pedicle groove imprinted into the posterior wall of the ventral apical chamber, and the deep dorsal median groove with chevron-like patterned surface are the shared features with topotypic specimens of $K$. clara. The external microornamentation of adult shells of this species was unknown to Mergl (2001a). This consists of fine circular pits of c. 1.5 to $2 \mu \mathrm{m}$ (Fig. 4C2). A similar microornament has been observed in the Devonian representatives of the genus: $K$. sp. from the Chýnice Limestone (mid-Emsian), K. robusta Mergl \& Jiménez-Sánchez, 2015 from the Suchomasty Limestone (late Emsian), and K. pulsatilla Mergl, 2009 from the Acanthopyge Limestone (Eifelian). The diameter of pits in all Devonian species varies around $2 \mu \mathrm{m}$ with the exception of the early neanic shell (Mergl 2009, Mergl \& Ferrová 2009, Mergl \& Jiménez-Sánchez 2015) and confirms the assignment of all these species to Kosagitella which has an overall stratigraphical range of Ludlow to Eifelian.

Occurrence. - Ludfordian, upper part of the Kopanina Formation, Opsiconidion parephemerus-Kosagittella clara Community, samples K2, K3, K4, K6, K8, K9, K10.

\section{Gen. et sp. indet.}

Material. - Three small fragments.

Remarks. - Despite their small size and poor preservation the fragments can be seen to belong to a moderately acuminate and thick-walled obolid shell, a glosseline or a pseudolingulide. This indicates the presence but also rarity of a large obolid brachiopod in a benthic association. The shells are not figured due to their poor preservation.

Occurrence. - Ludfordian, upper part of the Kopanina Formation, Opsiconidion parephemerus-Kosagittella clara Community, sample K5.

Family Paterulidae Cooper, 1956

\section{Genus Paterula Barrande, 1879}

Type species. - By original designation, Paterula bohemica Barrande, 1879 from the Vinice Formation (Sandbian, Ordovician) of the Prague Basin, Czech Republic.

\section{Paterula sp.}

Figure 4D

Material. - One complete dorsal valve and one shell fragment; figured specimen: JF195_87.

Remarks. - This is the first proved presence of this genus in the Ludlow of the Prague Basin. The shell is remarkable for its transparent valve. This distinguishes this species from other organophosphatic shells in our samples which 
are more or less distinguished by their brownish coloration. The same translucent shells have been observed in an early Mid Devonian paterulid from the Choteč Limestone (unpublished). This difference likely indicates a low amount of organic material in the shell wall of Paterula by comparison with other organophosphatic brachiopods. The genus has a worldwide spatial distribution and is known from the Dapingian (Mergl 1999) to the lower Eifelian (Mergl 2001a) in Bohemia.

Occurrence. - Ludfordian, upper part of the Kopanina Formation, Opsiconidion parephemerus-Kosagittella clara Community, samples K4, K5.

Superfamily Discinoidea Gray, 1840

Family Trematidae Schuchert, 1893

\section{Genus Schizobolus Ulrich, 1886}

Type species. - Lingula concentrica (Vanuxem, 1842), designated by Ulrich (1886), from the Middle Devonian of Tennessee, USA.

\section{Schizobolus sp.}

Figure 4F-H

Material. - One ventral valve and 11 incomplete valves; figured specimens: JF195_80, JF195_85 and JF195_88.

Description. - The dorsal valve is elongate to broadly oval, with its maximum width anterior to midlength. The posterior sector is gently sloping and very short. The valve is poorly convex in transverse profile and very weakly convex in the apical part becoming nearly flat in side view.

The ventral valve is moderate convex, with raised apex. The posterior slope is short, with broadly triangular catacline pseudointerarea halved by triangular pedicle opening. The surface of the pseudointerarea is clearly defined by an acute ridge. The shell interior is poorly known but lacks distinct impressions of muscles.

The macroornament consists of short, elevated, widely and evenly spaced entire rugellae, which are distinctly inclined forwards. Entire rugellae continue from the axial part of the shell to the posterior slope and entirely encircle the dorsal apex in the posterolateral part of the dorsal valve. New rugellae originate by intercalation between entire rugellae exclusively in the posterolateral sector of the valve. Interspaces have flat floors and are almost tentimes wider than rugellae.

Microornament consists of radial rays of vesicular pits separated by much wider, almost smooth surfaces. The pits may be solitary, aligned into simple rays or may be coupled forming complex and wider rays.
Remarks. - Schizobolus Ulrich, 1886 is previously considered to be an Early-Late Devonian genus (Holmer $\&$ Popov 2000). In the most recent diagnosis of this genus (Baliński \& Holmer 1999, Holmer \& Popov 2000) the pedicle opening is described as a triangular notch extending from the beak to the posterior margin, sometimes apically covered by a small listrium. The latest known species comes from the Famennian (Baliński \& Holmer 1999) but Schizobolus is more widespread in the Middle Devonian of South America (Clarke 1913, Mendez-Alzola 1938). Our specimens considerably precede the currently known Devonian range of the genus. However, the morphology of our specimens fits well with the diagnosis of the genus. The triangular pedicle notch bordered by narrow propareas, the shell outline and convexity, macroornament of low concentric rugellae and typically discinoidean microornament of radial rays of vesicular pits are remarkably similar to the Devonian representatives of Schizobolus. Furthermore, our Ludfordian Schizobolus $\mathrm{sp}$. is from a horizon deposited during the suggested peak of the Lau Event corresponding to the episode of cooling of the marine environment. It is worth noting that most occurrences of the South American Schizobolus species came from the presumed cold Malvinokaffric Realm (Boucot 1975, Morzadec et al. 2015).

Occurrence. - Ludfordian, upper part of the Kopanina Formation, Opsiconidion ephemerus Community, Kosoidea fissurella Community, and Opsiconidion parephemerus-Kosagittella clara Community, samples M13, M12, K1, K4, K8, K50, K59.

Family Discinidae Gray, 1840

\section{Genus Acrosaccus Willard, 1928}

Type species. - By original designation, Acrosaccus shuleri Willard, 1928 from the Rich Valley Formation (Caradocian, Ordovician) of Virginia, USA.

\section{Acrosaccus sp. A}

Figure 5L

Material. - One incomplete ventral valve; figured specimen: JF195_9.

Description. - The fragment of the valve is low conical, with moderately widening pedicle track covered by a gently concave listrium. The pedicle track has likely been closed posteriorly because its tapering is evident in the fragment (Fig. 5L1). The macroornament consists of weak concentric growth lines and concentric bands of uneven size. The microornament consists of shallow, broadly oval pits separated by narrower flat-topped 


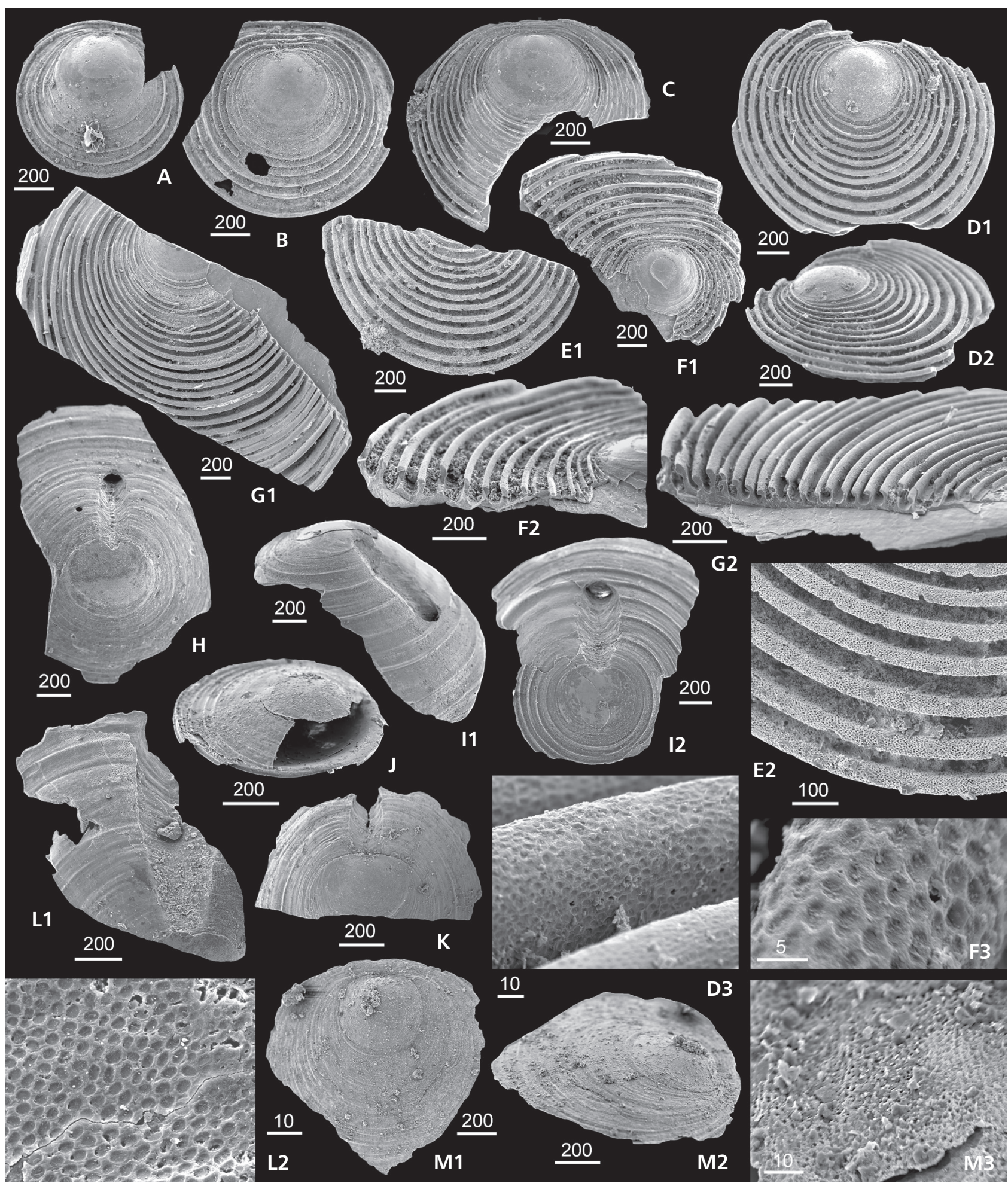

Figure 5. A-K - Chynithele vexata (Barrande, 1879), Kosov Quarry, samples K2 (A, B), K8 (D, F, H, I, J), K10 (C, E, G, K); A - exterior of small dorsal valve, JF195 30; B - exterior of dorsal valve, JF195 31; C - exterior of dorsal valve, JF195 5; D - exterior of dorsal valve (1), its anterodorsal view (2) and detail of its microornament (3), JF195_79; E - exterior of large incomplete dorsal valve (1), and its microornament (2), JF195_6; F - exterior of large incomplete dorsal valve (1), detail of ornament (2), and its microornament (3), JF195 81; G - exterior of incomplete dorsal valve (1), detail of ornament (2), JF195_7; H - exterior of incomplete ventral valve, JF195_82; I - exterior of incomplete ventral valve (2), and its posterolateral view (1), JF195_83; J - complete small shell, JF195_86; K - exterior of incomplete ventral valve, JF195_8. • L - Acrosaccus sp. A, Kosov Quarry, sample K10. Exterior of incomplete ventral valve (1) and its microornament (2), JF195_9. • M - Acrosaccus sp. B; Kosov Quarry, sample K8. Exterior of incomplete ventral valve (1), its laterodorsal view (2) and its microornament (3), JF195_84. Length of bars in $\mu \mathrm{m}$. 
interspaces. The length of the pits is about $5 \mu \mathrm{m}$. Pits are not arranged in discrete rows, being evenly scattered and chaotically oriented by their longer axes (Fig. 4L2).

Remarks. - The fragment differs from shells of other discinoideans in our samples by its different microornament and posteriorly expanding pedicle track. The fragment cannot be attributed to any known Silurian discinoidean from Bohemia. It is similar in its weakly ornamented ventral valve and microornament to Acrosaccus hallaensis Mergl, 2010a from the Halla Formation (Homerian) of Gotland.

Occurrence. - Ludfordian, upper part of the Kopanina Formation, Opsiconidion parephemerus-Kosagittella clara Community, sample K10.

\section{Acrosaccus sp. B}

Figure 5M

Material. - One incomplete dorsal valve; figured specimen: JF195 84.

Description. - The fragment comes from a subcircular dorsal shell having its submarginal apex covered by a distinctly convex larval shell. The posterior slope is steep and very short while the sides and anterior slopes are gently convex and moderately sloping. The macroornament consists of weak filose concentric lines densely covering the entire surface of the post-larval shell. The microornament consists of very fine, deep pits less than $2 \mu \mathrm{m}$ in diameter (Fig. 5M3).

Remarks. - Although incomplete, the specimen differs from the other discinoideans in our samples in its weak concentric macroornament and much finer pitting of the microornament.

Occurrence. - Ludfordian, upper part of the Kopanina Formation, Opsiconidion parephemerus-Kosagittella clara Community, sample K10.

\section{Genus Chynithele Havlíček in Havlíček \& Vaněk, 1996}

Type species. - By original designation, Chynithele ventricona Havlíček in Havlíček \& Vaněk, 1996 from the Chýnice Limestone (Emsian, Devonian) of the Prague Basin, Czech Republic.

\section{Chynithele vexata (Barrande, 1879)}

Figure 5A-K

1879 Discina vexata; Barrande, pl. 100, case 3, figs 1, 3, 4. 1879 Discina reversa. - Barrande, pl. 96, case 1, fig. 6.
1879 Discina planula. - Barrande, pl. 102, case 3.

2001a Acrosaccus vexatus. - Mergl, p. 26, pl. 19, figs 15, 16, pl. 20, figs 1-10.

Material. - 227 mostly small dorsal valves and 59 incomplete ventral valves; figured specimens: JF195_5-8, JF 195 30, JF195_31, JF195_79, JF195_81-83, and JF195_86.

Description. - See Mergl (2001a). The shell width may reach 4 or $5 \mathrm{~mm}$ (calculated from fragments). The pedicle track on the ventral valve is short, parallel-sided, with listrium clearly divided into a pair of wider sloping lateral plates and a narrower median plate. The external pedicle foramen is almost circular and continues internally into a long pedicle tube.

The macroornament of the dorsal valve consists of prominent, densely spaced concentric rugellae. They have moderately swollen crests which are extended toward shell periphery. Thinner shafts of the swollen rugellae crest rest almost vertically onto the shell surface (Fig. $5 \mathrm{G} 2$ ). The size of rugellae steadily and weakly increases with the growth of the specimens, with the earliest rugellae present just at the early post-larval shell stage. The most peripheral rugellae in large fragments are about two- to three-times higher than wide. Interspaces are deep and narrowly U-shaped. The macroornament of ventral valve is less distinct and is much finer than on the dorsal valve. It consists of fine rugellae steadily increasing in size. Rugellae are separated by much wider interspaces, having weak growth bands.

The microornament consists of subcircular concave vesicular pits of $c .5 \mu \mathrm{m}$ diameter arranged in a regular pattern. Radial rows of pits are distinct in the same parts of the shell, but generally their honeycomb arrangement prevails. Pits cover the entire external shell surface including interspaces and crests of rugellae but are missing on the larval shell.

Remarks. - Chynithele vexata (Barrande, 1879) is referred to Chynithele Havlíček in Havlíček \& Vaněk, 1996 due to the form of the macroornament with turned up dorsal rugellae which rapidly enlarge during shell growth. The difference of macroornament between the ventral and dorsal valve, flat lid-like dorsal valve, shape of the pedicle track and pedicle tube are further features that justified reassignment of this species that was figured but not described by Barrande (1879) to the genus Chynithele.

Occurrence. - Ludfordian, upper part of the Kopanina Formation, Opsiconidion ephemerus Community, Kosoidea fissurella Community and Opsiconidion parephemerus-Kosagittella clara Community, samples K59, K58, K57, K56, K53, M13, K2, K4, K5, K6, K7, K8, K9, K10, K11, K12, K13. 


\section{Kosoidea Havlíček \& Mergl, 1988}

Type species. - By original designation, Kosoidea fissurella Havlíček \& Mergl, 1988 from the Kopanina Formation (Ludfordian, Ludlow, Silurian) of the Prague Basin, Czech Republic.

\section{Kosoidea fissurella Havlíček \& Mergl, 1988 Figure 6}

1988 Kosoidea fissurella; Havlíček \& Mergl, p. 171, pl. 2, figs 4-8. 2001a Kosoidea fissurella. - Mergl, p. 27, pl. 21, figs 16-19.

Material. - Tens of small shell fragments; figured specimens: JF195_89-95.

Description. - See Havlíček \& Mergl (1988), with some additional comments given by Mergl (2001a). These descriptions we supplement here with details of its macroand microornament.

The macroornament of the dorsal valve consists of low concentric rugellae which gradually enlarged during shell growth and vary moderately in size (Fig. 6A). Rugellae are separated by broad interspaces with almost flat or weakly wavy surfaces. The first fine rugellae appear immediately after formation of the larval shell. The macroornament of the ventral valve is less regular. It is formed by semicircular rugellae rather irregularly spaced on the external surface (Fig. 6C1).

The microornament consists of rays of vesicular pits separated by almost smooth interspaces. The size of pits is almost uniform, c. 3-4 $\mu \mathrm{m}$. The pits are deep. Each consists of five or more clustered pits, indicating that the pits are imprints of clustered vesicles (Fig. 6B4). Some pits are aligned into a simple ray but more commonly the pits are coupled in a row or form rays of more aligned pits (Fig. 6G1, 6G2). Pits are better observable on the dorsal valve surface than on the ventral valve.

Remarks. - Despite previous descriptions (Havlíček \& Mergl 1988, Mergl 2001a) and the new material, some aspects of the general morphology of Kosoidea fissurella remain unknown. The most problematical is the detailed shape of the pedicle opening, which is likely posteriorly open, but our new material has provided no new data due to the very fragmentary state of preservation of all shells.

Occurrence. - Ludfordian, upper part of the Kopanina Formation, Kosoidea fissurella Community, samples M10, M3, K49, M16, K93, M11, M46, K1, M13.

\section{Genus Schizotreta Kutorga, 1848}

Type species. - By original designation, Orbicula elliptica
Kutorga, 1846 from the Volkhov or Kundan of the northwestern Russia.

\section{Schizotreta sp.}

Figure 4E

Material. - 21 dorsal and three ventral valves, all heavily fragmented; figured specimen: JF195_4.

Description. - The dorsal valve is thin-walled, with a much posteriorly placed beak, approximately $3-6 \mathrm{~mm}$ wide (calculated from fragments). The posterior slope is very short and weakly decreases from the arched domelike larval shell. The macroornament consists of few low and weak concentric rugellae, separated by broad interspaces having an uneven surface (Fig. 4E1). The microornament consists of small circular vesicular pits c. $2 \mu \mathrm{m}$ in diameter. Pits entirely cover the surface of the post-larval shell leaving almost no interspaces (Fig. 4E2).

Remarks. - The fragments represent species having a broadly oval and gently arched dorsal valve but we have no data about the ventral valve. The dorsal valve is very similar to the shell of Schizobolus Ulrich, 1886 but differs in its less posteriorly placed dorsal beak and by the different microornament of closely spaced small pits. That of Schizobolus consists of rays of vesicular pits separated by much wider smooth surfaces.

Occurrence. - Ludfordian, upper part of the Kopanina Formation, Opsiconidion ephemerus Community and Opsiconidion parephemerus-Kosagittella clara Community, samples K59, K58, K57, K56, K8, K9, K11.

Order Acrotretida Kuhn, 1949

Superfamily Acrotretoidea Schuchert, 1893

Family Torynelasmatidae Rowell, 1965

\section{Genus Acrotretella Ireland, 1961}

Type species. - By original designation, Acrotretella siluriana Ireland, 1961 from the upper Silurian of Oklahoma, USA.

Remarks. - The shell structure of Acrotretella has not previously been discussed in detail apart from a short note about its camerate structure by Holmer (1989; p. 110, fig. 76e). The presence of numerous small holes has been noted in Acrotretella spinosa Mergl, 2001a by Mergl (2001a; pl. 27, figs 7, 8). The holes penetrate the bottom of interspaces in a more or less regular concentric row or rows, with the largest hole aligned along the foot of rope-like concentric rugellae (Fig. 7E). The rugellae or subconcentric folds are never pierced by holes. A similar 


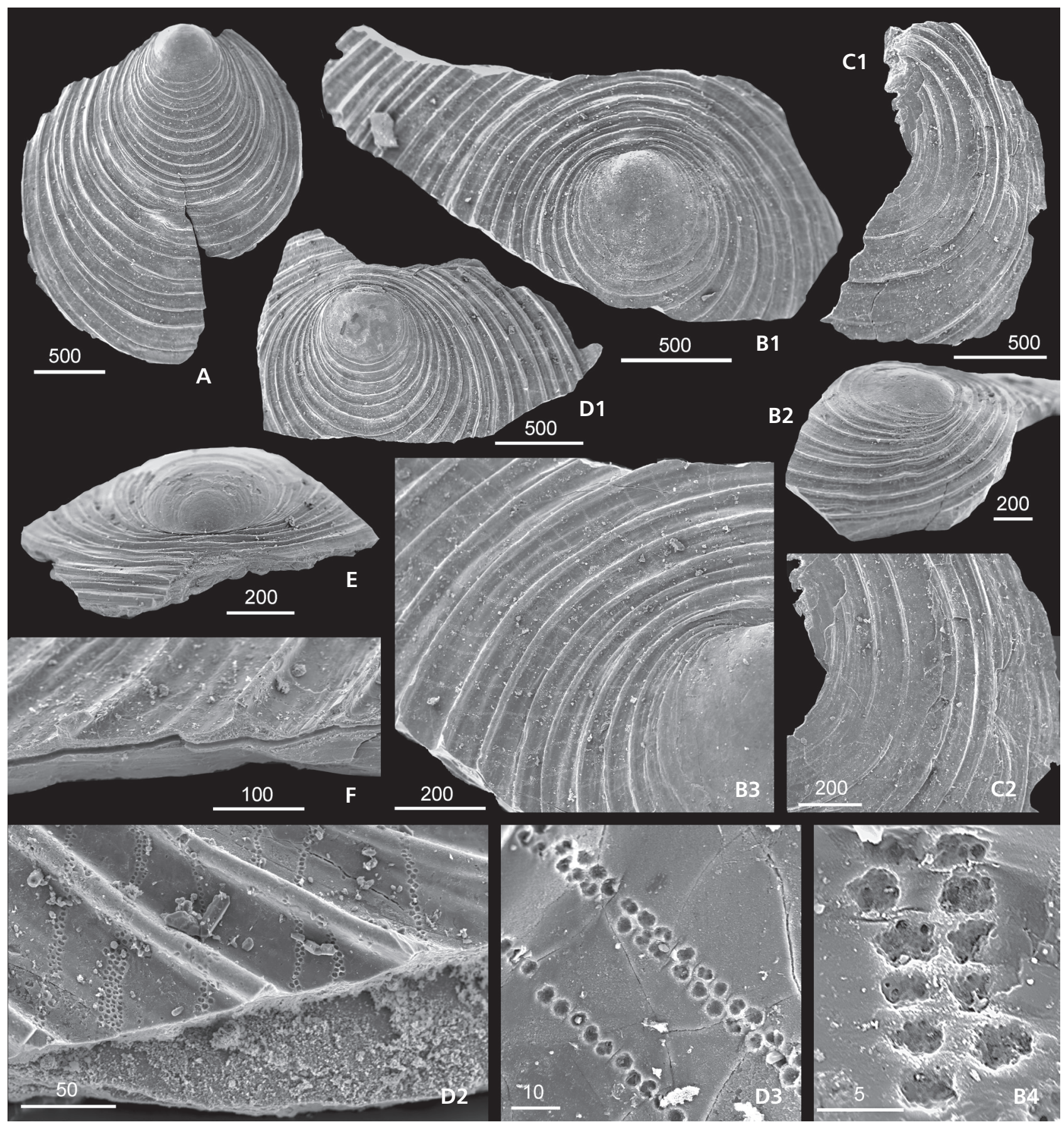

Figure 6. Kosoidea fissurella Havlíček \& Merg1, 1988, Kosov Quarry, sample M3 (all); A - exterior of incomplete dorsal valve, JF195_89; B - exterior of incomplete dorsal valve (1), its posterolateral view (2), detail of ornamentation (3) and its microornamentation (4), JF195_90; C - exterior of incomplete ventral valve (1) and its detail (2), JF195_91; D - exterior of incomplete dorsal valve (1), its microornament (2) and its detail (3), JF195_92; E - incomplete dorsal valve with the larval shell in posterior view, JF195_93; F - fragment of dorsal valve showing details of ornament, JF195_94. Length of bars in $\mu \mathrm{m}$.

arrangement of holes has been observed in specimens referred to A. siluriana, which have recently been extracted from the Kosov Section (sample K57). Detailed views of the ventral valve (Fig. 7B, C) show the coarsely camerate structure of shell wall, with honeycomb-like cylindrical chambers of c. 3-5 $\mu \mathrm{m}$ diameter. Most of the chambers have an external subcircular opening $2-3 \mu \mathrm{m}$ in diameter, surrounded by a small, funnel-like depression (Fig. 7B). Holes are restricted to interspaces between coarse, ropelike rugellae in the ventral valve, but are absent or rare on the ventral pseudointerarea. Holes are also absent or they are restricted to small groups on repaired parts of 
the shell (Mergl 2001a; pl. 27, fig. 7). The size of holes does not significantly differ between early and late growth stages of the shell. The first holes appear on the periphery of the brephic larval shell (Fig. 7A, D). These early holes are somewhat smaller and intercalated between small concentric growth lines. Holes were formed only in the thin primary layer, because these were not observed in thicker part of shell. In the living animal, these holes likely were filled with organic material. This interconnected the organic material of the chambers of the shell wall with the thin external organic layer outside the mineralized primary layer. The function of the holes is unclear. The nonmineralized parts of the shell likely decreased the weight of the shell and the "sandwich" structure made the shell more flexible and resilient against mechanical breakage. However, these holes may easily reflect recurrent episodes of more difficult biomineralization.

\section{Acrotretella siluriana Ireland, 1961}

Figures 7, 8H-P

1961 Acrotretella siluriana; Ireland, p. 1140, pl. 137, figs $13-18$.

2001a Acrotretella siluriana. - Mergl, p. 31, pl. 25, figs 1-17.
Material. - 32 dorsal and 13 ventral valves; figured specimens JF195_10, JF195_54-62.

Description. - The shell is $0.8 \mathrm{~mm}$ wide, transversely oval, moderately thick, having a nearly straight posterior margin and evenly rounded sides and anterior margin rectimarginate.

The dorsal valve is weakly convex, without any sign of a sulcus. The dorsal larval shell is circular, c. $170 \mu \mathrm{m}$ wide having a gently folded surface. The central node is highest in its posterior part being backwards and posterolaterally bounded by a depressed halo. The larval shell bears shallow, flat-bottomed regularly circular pits of 0.7 to $1.5 \mu \mathrm{m}$ diameter. The pits are intersect with smaller pits below more external larger ones. The dorsal pseudointerarea occupies $50 \%$ of the valve width and $7 \%$ of the valve length. The median groove is broadly triangular, poorly concave, laterally passing into small shorter narrowly triangular propareas. The anterior edge of the median groove is straight and shortly undercut. A broad flat marginal brim is distinct, surrounding the shallow concave visceral surface, which lacks any signs of muscle scars and lateral processes. The median septum starts at the posterior one-third of the valve and disappears shortly

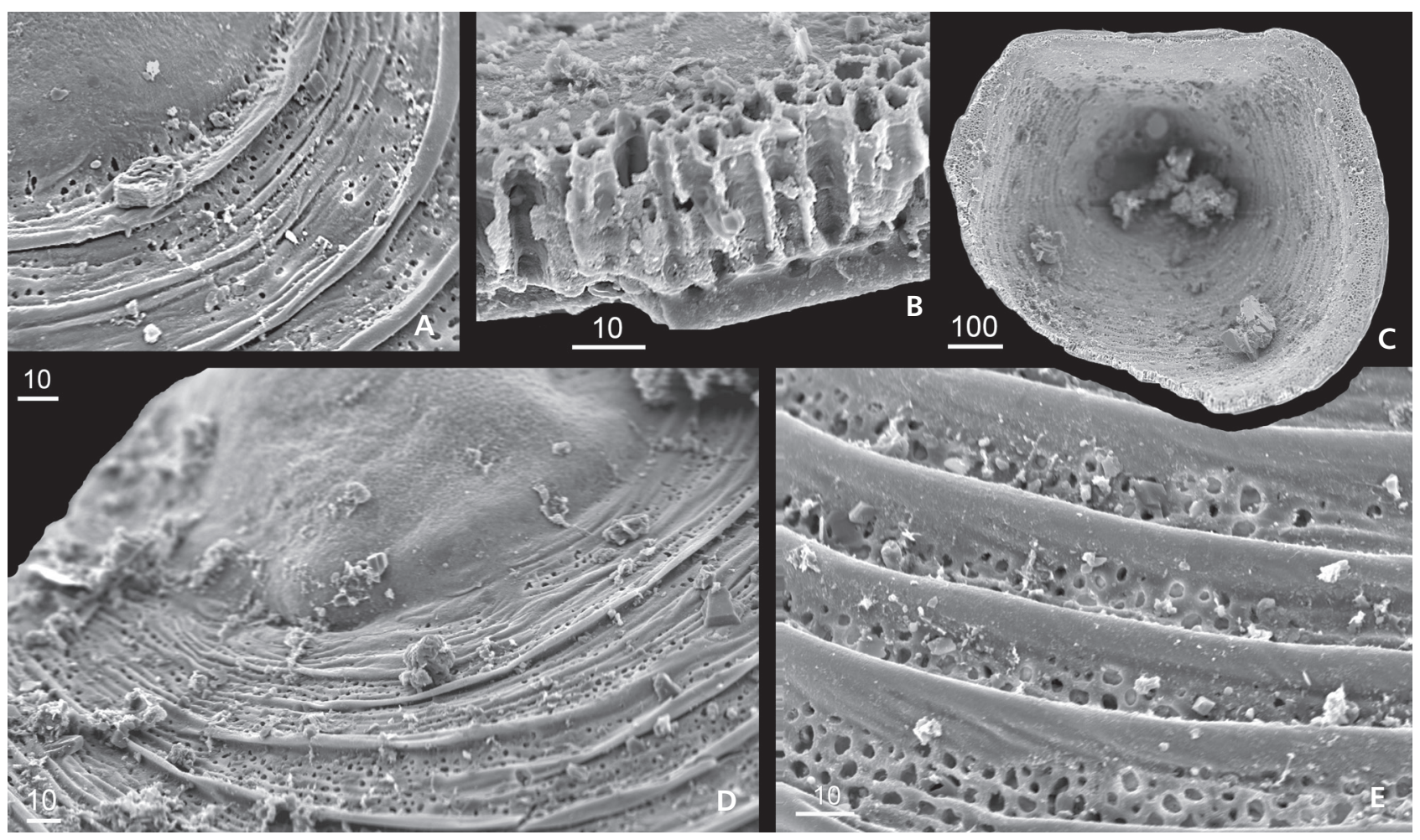

Figure 7. Acrotretella siluriana Ireland, 1961, Kosov Quarry, sample K57 (all); A - exterior of dorsal larval shell and early post-larval shell showing scattered holes, JF195_60; B - broken shell of ventral valve showing the camerate structure of the wall, JF195_62; C - interior of the ventral valve showing camerate structure of shell wall, JF195_62; D - exterior of dorsal larval shell and adjacent surface of post-larval shell, JF195_57; E - exterior of ventral valve showing oblique ridges on concentric rugellae and rows of holes in interspaces, JF195_61. Length of bars in $\mu \mathrm{m}$. 
from the marginal brim. The posterior half of the median septum bears a short and poorly concave surmounting plate. The anterior half of the septum is blade-like with its front edge extended into short digitate projections.

The ventral valve is high conical, with a depressed catacline pseudointerarea. Lateral and anterior slopes are straight. The apex is directed posteroventrally, with a distinct dome-like larval shell formed by a pair of side nodes and a lower posterior node. The circular pedicle foramen is located anteriorly to the posterior node and is ventrally directed. The pseudointerarea is delimited by a sharp change of valve convexity. Its sides bear similar ornament to the rest of the valve, but concentric rugellae almost vanish in the narrowly triangular sector corresponding to the median groove of the dorsal pseudointerarea (Fig. 8N2).

The macroornament consists of rope-like concentric rugellae almost evenly spaced over the shell surface. Interspaces are as wide as or slightly narrower than rugellae. Minute holes are aligned in irregular bands in the surface of interspaces.

Remarks. - The specimens cannot be distinguished from the shells referred to Acrotretella siluriana Ireland, 1961 from the Motol Formation (Mergl 2001a) of the Bohemian Silurian. The relation to $A$. siluriana to A. triseptata Mergl, 2001a is discussed below.

Occurrence. - Ludfordian, upper part of the Kopanina Formation, Opsiconidion ephemerus Community and Opsiconidion parephemerus-Kosagittella clara Community, samples K59, K58, K57, K56, K52, K50, K7, K8, K9, K10.

\section{Acrotretella triseptata Mergl, 2001a}

Figure $8 \mathrm{~A}-\mathrm{G}$

2001a Acrotretella triseptata; Mergl, p. 32, pl. 27, figs 9-11.

Material. - 20 dorsal and nine ventral valves; figured specimens JF195_32-38.

Diagnosis. - Emended: Acrotretella with spinose median septum and paired, anteriorly digitate lateral processes present already in early growth stages; ventral pseudointerarea with poorly defined concentric rugellae; rugellae rounded, densely arranged, regularly spaced over shell surface.

Description. - See Mergl (2001a). The ventral valve is highly conical, transversely oval in outline in apical view, with evenly curved sides and a less curved anterior margin. The anterior commissure is rectimarginate. The apex is directed ventrally. Anterior and lateral slopes are straight. The pseudointerarea is catacline and distinctly flattened. The larval shell is circular and highly convex, in its central part pierced by a circular ventrally directed pedicle foramen. This is located in the floor of a depression laterally bordered by high lateral nodes. The interior of the ventral valve lacks distinct muscle scars. The asymmetrical development of the shell may be prominent (Fig. 8D).

The macroornament is formed by concentric ropelike rugellae arranged in a fairly regular manner. The interspaces are wider than the rugellae on a neanic shell, but their width decreases with growth and adult shells have tightly adjoined rugellae separated by narrow interspaces. The surface of the interspaces bears low subconcentric uneven growth lines.

Remarks. - The species was erected on dorsal valves. Therefore a new diagnosis and description are presented here. Specimens referred to Acrotretella triseptata Mergl, 2001a from the post-Lau interval of the Kopanina Formation are distinct in having two lateral processes placed anterolaterally on each side of the median septum. The median septum and processes have spinose anterolateral edges. A similarly triseptate arrangement is known already in A. goldapiensis Biernat \& Harper, 1999 from the Dapingian (= upper Llanvirnian) of Poland. Similar $A$. sp. having one or two pairs of lateral processes was described by Valentine et al. (2006) from the upper Llandovery of New South Wales. The same authors (Valentine et al. 2006) further erected A. dizeugosa sp. nov. characterized by two pairs of long and slender lateral processes. This species comes from the Cobra Formation (Ludlow) of New South Wales. Valentine et al. (2006) discussed in detail the ontogeny of 34 dorsal valves of

Figure 8. A-G - Acrotretella triseptata Mergl, 2001a, Kosov Quarry, sample K2 (all); A - interior of incomplete dorsal valve (1) and its side view (2), JF195_32; B - interior of dorsal valve, JF195_33; C - interior of incomplete dorsal valve, JF195_34; D - exterior of ventral valve in apical (1), lateral (2), and posterior (3) views , JF195_35; E - interior of small dorsal valve in lateral (1) and ventral views (2), JF195_36; F - exterior of complete shell in posterior (1), lateral (2), and apical (3) views, JF195_37; G - exterior of dorsal valve (1), and its oblique view (2), JF195_38. • H-P - Acrotretella siluriana Ireland, 1961, Kosov Quarry, samples K10 (H), K57 (I-P); H - interior of small dorsal valve in oblique (1) and ventral views (2), JF195_10; I - interior of dorsal valve, JF195_54; J - interior of dorsal valve (1) and its side view (2), JF195_55; K - interior of dorsal valve, JF195_56; L - exterior of dorsal valve (1), and its oblique (2) view, JF195_57; M - exterior of ventral valve in apical (1), and posterolateral (2) views, JF195_58; $\mathrm{N}$ - exterior of ventral valve in apical (1), and posterior (2) views, JF195_59; O - exterior of dorsal valve (1), its larval shell (2) and detail of protegular pitting (3), JF195_60; P - exterior of ventral valve in posterior view, JF195_61. Length of bars in $\mu \mathrm{m}$. 


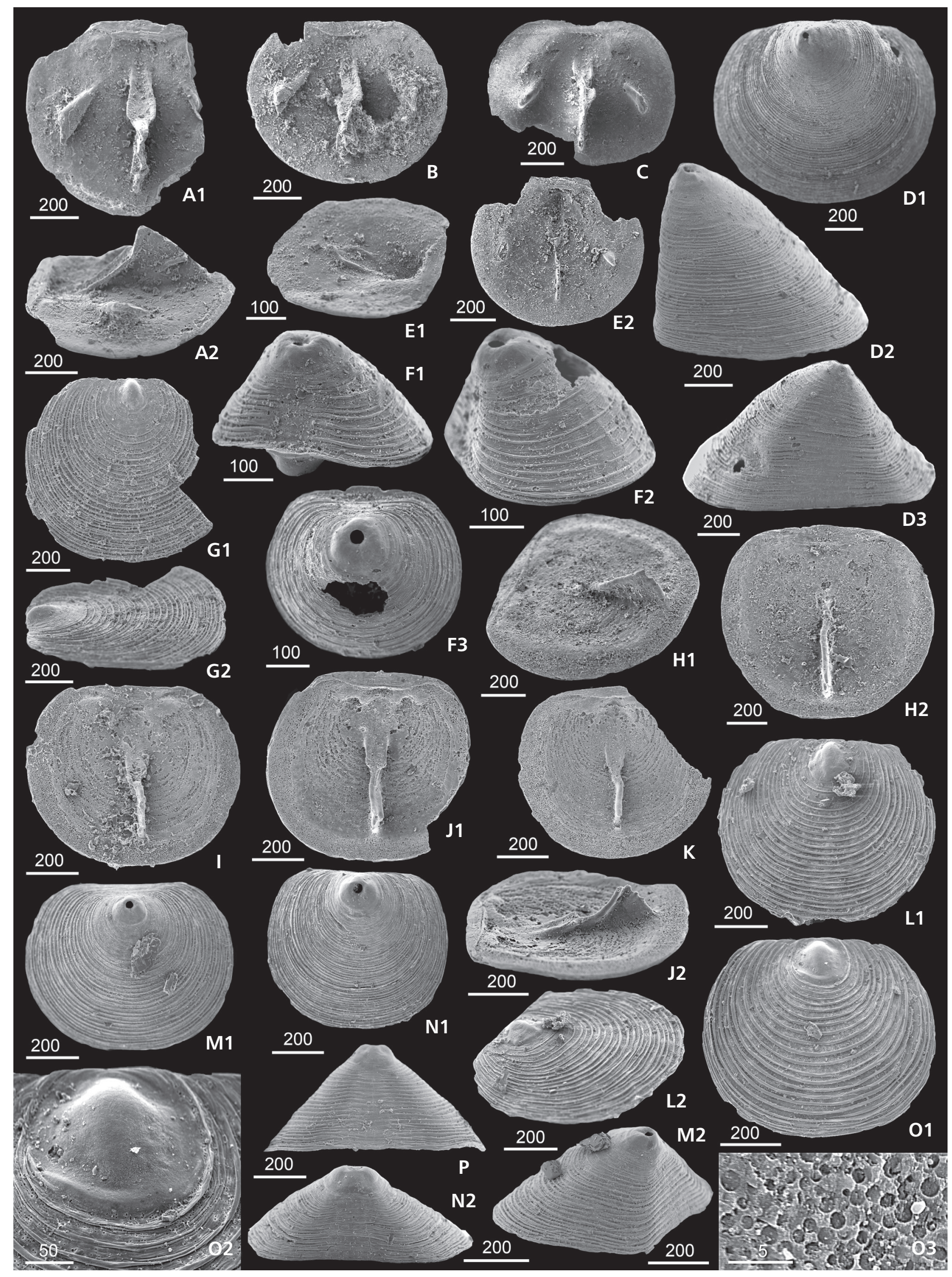


A. dizeugosa. They suggest that lateral processes appear during ontogeny starting with the small dorsal valve having only the median septum. A similar arrangement of lateral processes is known in "Acrotretid gen. et. sp. nov." from the Katian of Ireland (Wright \& McClean 1991).

However, there are also unnamed species without lateral processes, from the Upper Ordovician of Sweden (Holmer 1986, 1989) and Kazakhstan (Popov 2000). Further species lacking the lateral processes are known from the Llandovery of New South Wales, Australia (Valentine et al. 2003) and the Czech Republic (Mergl 2001a), in the Wenlock of Oklahoma, Australia, and the Czech Republic (Ireland 1961, Mergl 2001a, Valentine et al. 2003), and the Př́dolí of Australia and the Czech Republic (Klyza 1997, Mergl 2001a). There is evidently a long stratigraphical overlap of species bearing or lacking lateral processes.

The new material from the Czech Republic indicates the presence of lateral processes developed as a small but distinct acute node in the small valves (Fig. 8E). The earliest specimens of $A$. triseptata occur in the post-Lau Event interval of the Kopanina Formation. Unlike these, the largest known specimens of Acrotretella in the preLau Event interval (samples K59, K58, K57, K56, K52, $\mathrm{K} 50$ ) are always without lateral processes. Specimens of A. spinosa Mergl, 2001a of Př́dolí age from the Czech Republic lack lateral processes although there are dorsal valves having a very high and anteriorly multispinose median septum (Mergl 2001a, pl. 26, fig. 6) that indicate the late adult growth stage of specimens. We assume from the presently known data about the ontogeny and evolutionary history of Acrotretella that two lineages exist in the evolutionary history of the genus. An absence of lateral processes is a likely apomorphy derived in the Late Ordovician because the oldest $A$. goldapiensis has lateral processes fairly well developed. The original branch keeping the lateral processes persisted until the Lochkovian (Mergl 2001a) and possibly the Pragian (Valentine 2006a). The poorly preserved ventral valve described from the Pragian (Valentine 2006a) has a nearly smooth ventral pseudointerarea, a feature which has been observed in the newly collected $A$. triseptata from the post-Lau Event interval.
Occurrence. - Ludfordian, upper part of the Kopanina Formation, Opsiconidion parephemerus-Kosagittella clara Community, samples K2, K3, K5.

Family Biernatidae Holmer, 1989

\section{Genus Opsiconidion Ludvigsen, 1974}

Type species. - By original designation, Opsiconidion arcticon Ludvigsen, 1974 from the Emsian (Devonian) of Yukon, Canada.

\section{Opsiconidion ephemerus (Mergl, 1982)}

Figure 9A-L

1982 Caenotreta ephemera; Mergl, p. 115, pls 1, 2.

2001a Opsiconidion ephemerus. - Mergl, p. 33, pl. 29, figs 1-9.

Material. - 129 dorsal and 243 ventral valves, mostly complete; figured specimens JF195_63-74.

Description. - See Mergl (1982, 2001a). The new specimens show some fine details of microornament formerly unobserved. The concentric growth lines of neanic and adult shells are crossed by drape-like folds of nearly uniform size (Fig. 9K2). Much finer radial uniformly sized striations that are fairly regular distributed are superimposed on those folds and growth lines (Fig. 9G2). These striae differ from the deep radial striations of inconstant size which are present on the surface of the ventral pseudointerarea (Fig. 9K5). Fine striae likely represent the imprints of cell vesicles or boundaries of epithelial cells on the secretory margin of the mantle. Irregular deeper striations on the ventral interarea likely originated by infolding or damage of the outer organic layer at the mechanically stressed junction of the dorsal and ventral pseudointerareas.

Remarks. - The new material from the Kopanina Formation indicates that there is higher diversity of biernatids than previously suggested. Mergl (2001a) noted that Opsiconidion ephemerus (Mergl, 1982) appears at the base of the Cromus beaumonti Horizon and extends to the lower

Figure 9. A-L - Opsiconidion ephemerus (Mergl, 1982), Kosov Quarry, sample K57 (all); A - interior of dorsal valve (1) and its side view (2), JF195_63; B - interior of dorsal valve (1) and its side view (2), JF195_64; C - interior of dorsal valve, JF195_65; D - exterior of dorsal valve, JF195_66; E - exterior of dorsal valve, JF195_67; F - exterior of dorsal valve (1) and its larval shell (2), JF195_68; G - exterior of ventral valve in anterolateral view (1) and its ornament (2), JF195_69; H - exterior of ventral valve in ventral view, JF195_70; I - exterior of ventral valve in side view, JF195_71; J - exterior of small ventral valve in side view, JF195_72; K - exterior of ventral valve in side view (1), its exterior in posterior view (2), its ornamentation (3), detail of its apex (4), detail of its pseudointerarea (5), and pitting of its larval shell (6), JF195_73; L - larval shell of dorsal valve, JF195_74. - M-P - Opsiconidion bouceki sp. nov., Kosov Quarry, sample K8 (all); M - interior of dorsal valve in ventral (2) and its side views (1), JF195_75; N - exterior of ventral valve in side view (1), detail of larval pitting (2), larval shell (3) and detail of its apex (4), JF195_76; O - exterior of ventral valve, JF195_77; P - exterior of ventral valve in side view, JF195_78. Length of bars in $\mu \mathrm{m}$. 


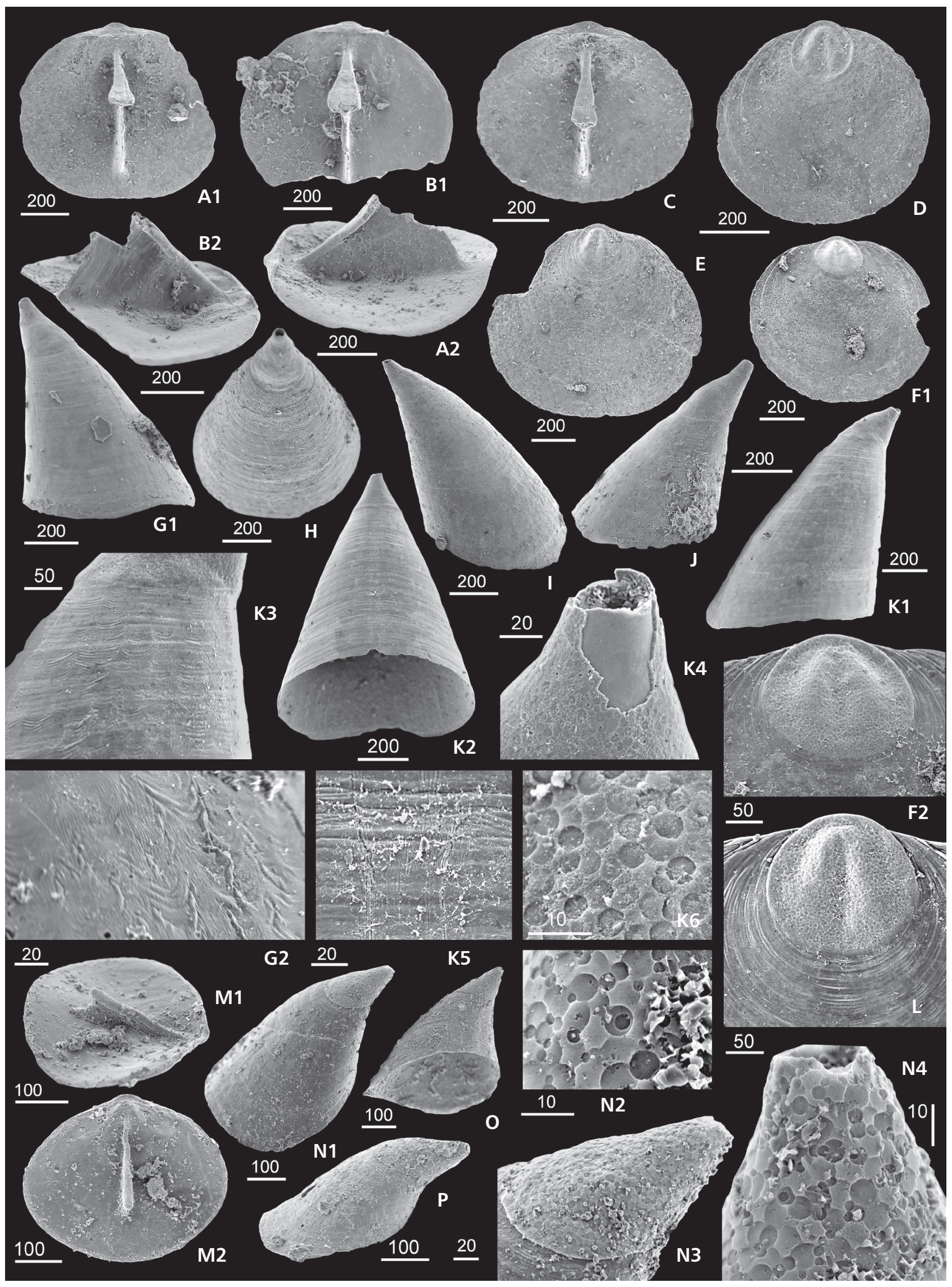


or even middle part of the Požáry Formation (Přídolí). Actually the stratigraphical range of $O$. ephemerus is much shorter. The type collection comes from the lower part of the Kopanina Formation (Cromus beaumonti Horizon). The topotypic specimens are characterized by the flattened upper rod of the dorsal septum. This feature has been observed also in all biernatids coming from the beds with Diacanthaspis (A.) minuta in the Kosov Section. This part of the section precedes the onset of the Lau Event. No studied biernatid dorsal valve collected above the Lau Event maximum has a distinctly flattened upper rod and therefore cannot be attributed to $O$. ephemerus. We suggest that the stratigraphical range of $O$. ephemerus is restricted to the lower part of the Kopanina Formation. The published data about its occurrence above the Lau Event interval are incorrect and concern different, although morphologically very similar species described herein.

Occurrence. - Ludfordian, upper part of the Kopanina Formation, Opsiconidion ephemerus Community, samples K58, K57, K56, K54, K53, K52, K51, K50.

\section{Opsiconidion bouceki sp. nov.}

Figures 9M-P, 10Q-T

Holotype.-JF195_75, the dorsal valve figured in Fig. 9M.

Type horizon and locality. - Ludfordian, Kopanina Formation, upper part. Czech Republic, Beroun, Kosov Hill, abandoned quarry.

Material. - 25 dorsal and 195 ventral valves, both complete and fragmentary; figured specimens JF195_1214, 16, JF195_75-78.

Etymology. - After Prof. Bedřich Bouček, the outstanding Czech palaeontologist of the $20^{\text {th }}$ century.

Diagnosis. - Opsiconidion distinctive by its small size, very thin post-larval shell wall, acutely conical ventral valve having distinct apsacline ventral pseudointerarea, transversely broadly elliptical dorsal valve, weakly unisulcate commissure, low blade-like dorsal median septum having only upper rod; macroornament of weak concentric growth lines; ventral larval shell with pedicle foramen directed moderately posteroventrally; protegular pitting with circular imprints of uneven size arranged in more layers.

Description. - Shell small, $0.5 \mathrm{~mm}$ wide, thin-walled. The dorsal valve is transversely broadly elliptical, with a shallow sulcus and small and short anacline pseudointerarea. Dorsal valve interior has low to moderately high very thin median septum bearing thin upper rod. The lower rod is not observable.

The ventral valve is highly conical, with broad, flattened apsacline pseudointerarea. The larval shell is asymmetrically conical, with circular foramen directed posteroventrally.

Macroornament of shell consists of fine growth lines. Microornament of the larval shell consists of circular flat-based imprints of discoid tablets. The surface is a mosaic of entire and lunate imprints. There were several successive stages of imprint formation, with the first layer formed by the largest tablets. Imprints vary greatly in diameter within the same larval shell $(2.0-4.2 \mu \mathrm{m})$.

Remarks. - Opsiconidion bouceki sp. nov. is similar in its apsacline ventral pseudointerarea, low dorsal median septum, and protegular pitting having numerous lunate imprints to O. simplex Mergl, 2001a from the Požáry Formation (Př́idolí). The latter differs in its more rounded dorsal valve having an extended posterior part with correspondingly longer dorsal pseudointerarea, and more distinct ventral sulcus.

The species differs from the associated $O$. parephemerus sp. nov. by its flattened apsacline ventral pseudointerarea, different shape of dorsal median septum and by the different mosaic of circular imprints on the larval shell. The protegular microornament of $O$. parephemerus and O. ephemerus (Mergl, 1982) consists of an evenly spaced, uniformly sized simple mosaic (Figs 9K6, 10F4) whereas the imprints are intersected and tablets were arranged in several layers in O. bouceki sp. nov. (Figs. 9N2, N4, 10U2).

Occurrence. - Ludfordian, upper part of the Kopanina Formation, Opsiconidion parephemerus-Kosagittella clara Community, samples K2, K4, K5, K6, K8, K9, K10.

\section{Opsiconidion parephemerus sp. nov.}

Figure 10A-P

Holotype.-JF195_45, the dorsal valve figured in Fig. 10G.

Type horizon and locality. - Ludfordian, Kopanina Formation, upper part. Czech Republic, Beroun, Kosov Hill, abandoned quarry.

Material. - 227 dorsal and 217 ventral valves, mostly complete; figured specimens JF195_11, JF195_39-53.

Etymology. - Prefix para- (Latin) refers to the morphological similarity to the ancestral Opsiconidion ephemerus.

Diagnosis. - Opsiconidion distinctive by its acutely conical ventral valve having narrow and weakly defined 
catacline ventral pseudointerarea, weakly unisulcate commissure, blade-like dorsal median septum of moderate height with unflattened upper rod and longer and weaker lower rod; macroornament of weak concentric growth lines; ventral larval shell with pedicle foramen directed slightly posteroventrally; protegular pitting primarily unilayered, of almost uniformly sized circular imprints.

Description. - Shell $1.0 \mathrm{~mm}$ wide, thin-walled, with weakly unisulcate commissure.

The dorsal valve is flat, circular to subpentagonal in outline, $90-95 \%$ as long as wide. The maximum width is at or anterior to shell midlength. The valve is almost flat with broad shallow sulcus distinct from neanic shell. The dorsal pseudointerarea is anacline and widely triangular, $55-60 \%$ as wide as the valve, with shallow weakly defined median groove and large triangular propareas. Anterior margins of the median groove and propareas are shallowly excavated and weakly arched posteriorly or straight, respectively. Posterolateral periphery of the shell interior is reinforced and forms a narrow brim which fades anteriorly from valve midlength. The dorsal median septum is blade-like, extending from the apical chamber almost to the anterior margin of the shell. The septum is of moderate height, having the highest point at about $30 \%$ of septum length. Ventral edge of septum bears massive rounded rod with rounded tip. The lower rod is less distinct, of smaller diameter and is tightly subjacent to the upper rod. The rounded end of the lower rod forms the highest tip of the septum. The upper rod is very weakly but clearly concave in side view. Muscle impressions are weakly delimited with large cardinal muscle scars, which extend to $40 \%$ of the valve length. The scars are separated from the median septum by a deep narrowly triangular depression. Its posterior slope is marked by several epithelian cell moulds. The dorsal larval shell is subcircular, c. $150 \mu \mathrm{m}$ wide having a pair of nodes which are fused posteriorly. Anterior margin of larval shell is marked by thickened rim and lack of protegular pitting. The posterolateral margins of the larval shell are elevated above the brephic shell. The posterior of the larval shell extends slightly beyond the posterior margin of the shell. The upper surface of the larval shell is covered by shallow circular pits 3 to $5 \mu \mathrm{m}$ in diameter which are usually entire and each separated by elevated interspaces.

The ventral valve is acutely conical, about $180 \%$ as high as wide with the apex directed weakly posteroventrally. Anterior and lateral slopes are straight. The pseudointerarea is catacline narrowly triangular and distinct by gently inflation of shell surface. The ventral larval shell is asymmetrically conical, apically pierced by the circular pedicle foramen, which is directed gently posteroventrally. Incline of the posterior slope of the larval shell is steeply apsacline but near to the incline of the pseudointerarea. Anterior slope of larval shell is nearly straight having only poor convexity near its margin. The outer surface of the ventral larval shell is covered by shallow circular pits of the same arrangement and size as on the dorsal larval shell.

The exterior of both valves bears weak concentric growth lines more distinct in posterolateral sectors of valves. Fila fade on the surface of the ventral pseudointerarea. An asymmetrical drape-like subconcentric external ornament is not common.

Remarks. - The new species is very similar to the ancestral Opsiconidion ephemerus (Mergl, 1982). The main difference is the nature of the dorsal median septum. The upper rod is always rounded and never forms the narrowly triangular plate that is present in O. ephemerus. This difference is not related to ontogenic changes within O. parephemerus (Fig. 10A-G) because the largest valves are also distinctive because of their unflattened upper rod. The specimens referred to $O$. ephemerus from the same locality but from the earlier stratigraphical interval, before the Lau Event differ also by their less tightly subjacent lower rod and by their external ornamentation, which embraces also drape-like subconcentric structures (Fig. 9G2, K3).

Opsiconidion simplex (Mergl, 2001a) from the Požáry Formation (Prrídolí) differs from the new species in its apsacline ventral pseudointerarea, abundant drapelike folds in the external ornamentation, much smaller dorsal pseudointerarea, and low dorsal median septum having only an upper rod. The protegular pitting of $O$. simplex is notable for the intersection of circular pits indicating a multi-layered arrangement of circular tablets. The primary unilayered disposition of protegular pits distinguishes $O$. parephemerus also from other biernatids of Silurian age from Bohemia (Mergl 2001a).

Occurrence. - Ludfordian, upper part of the Kopanina Formation, Opsiconidion parephemerus-Kosagittella clara Community, samples K2, M12, K3, K5, K7, K8, K10, K11, K12, K13.

Superfamily Siphonotretoidea Kutorga, 1848

Family Siphonotretidae Kutorga, 1848

Genus Orbaspina Valentine \& Brock, 2003

Type species. - By original designation, Orbaspina gelasinus Valentine \& Brock, 2003 from the Wenlock (Silurian) of New South Wales, Australia.

\section{Orbaspina chlupaci Mergl, 2003}

Figure 11A-M 
2001a Siphonotretid sp. A. - Mergl, p. 350, fig. 53.3f, g. 2001b Siphonotretine sp. - Mergl, p. 38, figs 8-10.

2003 Orbaspina chlupaci; Mergl, p. 420, pl. 1, figs 1-5.

Material. - 35 dorsal and 8 ventral valves; figured specimens JF195_17-29.

Description. - See Mergl (2003) for the description of the dorsal valve. Shell is about $1.5 \mathrm{~mm}$ wide (calculated from fragments). The ventral valve is very thin having an acute beak, with posterolateral margins enclosing a $c$. $150^{\circ}$ angle. The ventral pseudointerarea is low, apsacline, formed by a broadly triangular median groove and inclined to narrowly triangular propareas which extend far forward alongside the shell edge. The pedicle opening is broadly triangular, become more elongate during growth, posteriorly closed by an outwardly united gently concave plate. The low arcuate brim on the exterior of the concave plate (Fig. 11A1, I) indicates the position of the posterior wall of the anteriorly migrating pedicle. This plate is internally bilobed having a thinner and internally infolded median suture. The exterior of the ventral valve is characterized by shallow irregular pits and a row of thin and very short hollow spines.

The ornamentation of the dorsal valve consists of dense subconcentric rows of shallow pits, short massive hollow tubes along the posterior shell margin and minute circular holes.

Remarks. - The dorsal valve exterior is notable by three structures related to the spinose ornament. The first is shallow pitting. The pits shallow forwards and their size and arrangement in irregular concentric bands likely corresponds to the alignment of spines along the shell margins. A short ridge between two pits likely formed a protective structure above the proximal part of each nonmineralized hollow spine. The arrangement and length of such spines are likely traceable on a single dorsal valve (Fig. 11B1). There the concentric growth band is surrounded by radially arranged thin slits. These slits likely originated by imprinting of organic-walled hollow spines extending from the periphery of the valve into the secreted mineralized shell during next phase of shell growth (Fig. 10B2). The density and disposition of these slits indicate the radial arrangement, uneven size and high density of spines along shell margin.

The heavily mineralized hollow spines are the second distinctive structure of the dorsal valves of $O$. chlupaci Merg1, 2003 (Fig. 11B1, D1, D2, J1, J2). These hollow tubular spines are restricted to the posterior margin of dorsal valves. Spines are short, extending internally from the shell edge behind the dorsal pseudointerarea. The distal ends of spines often converge towards the plane of shell symmetry. The massive, posteriorly facing hollow spines likely fixed the shell to a firm substrate ( $c f$. Wright \& Nõlvak 1997).

Formerly unknown holes vertically penetrating the dorsal valve are the third notable feature of the Orbaspina shell. These holes are circular, about $12-15 \mu \mathrm{m}$ in diameter, sparsely but equally scattered on the valve. Each hole continues into short canal disposed orthogonally to the shell lamination. Externally, any hole does not continue with hollow spine (Fig. 11E5, 6). Externally, the holes are surrounded by shallow funnel like depression (= antechambers by Williams et al. 2004). Internally, these holes are encircled by several phosphatic laminae, forming knob-like structures in the shell interior (Fig. 11M1-M3). A mineralized layer never seals the canals. This indicates that canals accomodated the vital soft structure for the whole life of the animal. Popov et al. (2009) bring evidence about presence of setae inside the hollow spines of Siphonobolus. The extensions of soft tissue in Orbaspina similar to the setae of Siphonobolus were internally surrounded by mantle tissue with a higher affinity to biomineralization. This tissue formed a mineralized knob at base of each seta. Unlike the setae of Siphonobolus none of setae in Orbaspina was outwards protected by mineralized tubes. The setae of Orbaspina were oriented dorsally, anterodorsally and posteriorly. This is evident from few mineralized hollow knobs hidden below the dorsal pseudointerarea in the shell interior. The diameter of the canals, their paucity on the shell surface, permanent opening and their orientation indicate a different function of these setae from the peripheral spines. The setae protruding from the large holes were likely a component of the sensoric or protective apparatus

Figure 10. A-P - Opsiconidion parephemerus sp. nov., Kosov Quarry, samples K2 (A-Q), K10 (P); A - interior of small dorsal valve, JF195_39; B - interior of small dorsal valve, JF195_40; C - interior of dorsal valve (1) and its posterolateral view (2), JF195_41; D - interior of dorsal valve (1) and its anterior view (2), JF195_42; E - interior of dorsal valve (1) and its side view (2), JF195_43; F - exterior of dorsal valve in side (1) and dorsal (2) views, its larval shell (3) and protegular pitting (4), JF195_44; G - interior of dorsal valve (1), its side (2) and oblique (3) views, JF195_45; $\mathrm{H}$ - interior of dorsal valve in side view, JF195_46; I - exterior of dorsal valve, JF195_47; J - interior of ventral valve, JF195_48; K - exterior of ventral valve in anterior view, JF195_49; L - exterior of ventral valve in posterior view, JF195_50; M - exterior of small ventral valve in side view, JF195_51; N - exterior of small ventral valve in side view (1), and its larval shell (2), JF195_52; O - exterior of large ventral valve in posterolateral view, JF195_53; P - exterior of complete shell, JF195_11. - Q-T - Opsiconidion bouceki sp. nov., Kosov Quarry, sample K10 (all); Q - interior of dorsal valve, JF195_12; R - exterior of ventral valve in ventral (1), side (2), posterolateral (3) and lateral views (4), JF195_13; S - exterior of ventral valve in posterior view, JF195_14; T - larval shell of ventral valve (1), and its protegular pitting (2), JF195_16. Length of bars in $\mu \mathrm{m}$. 


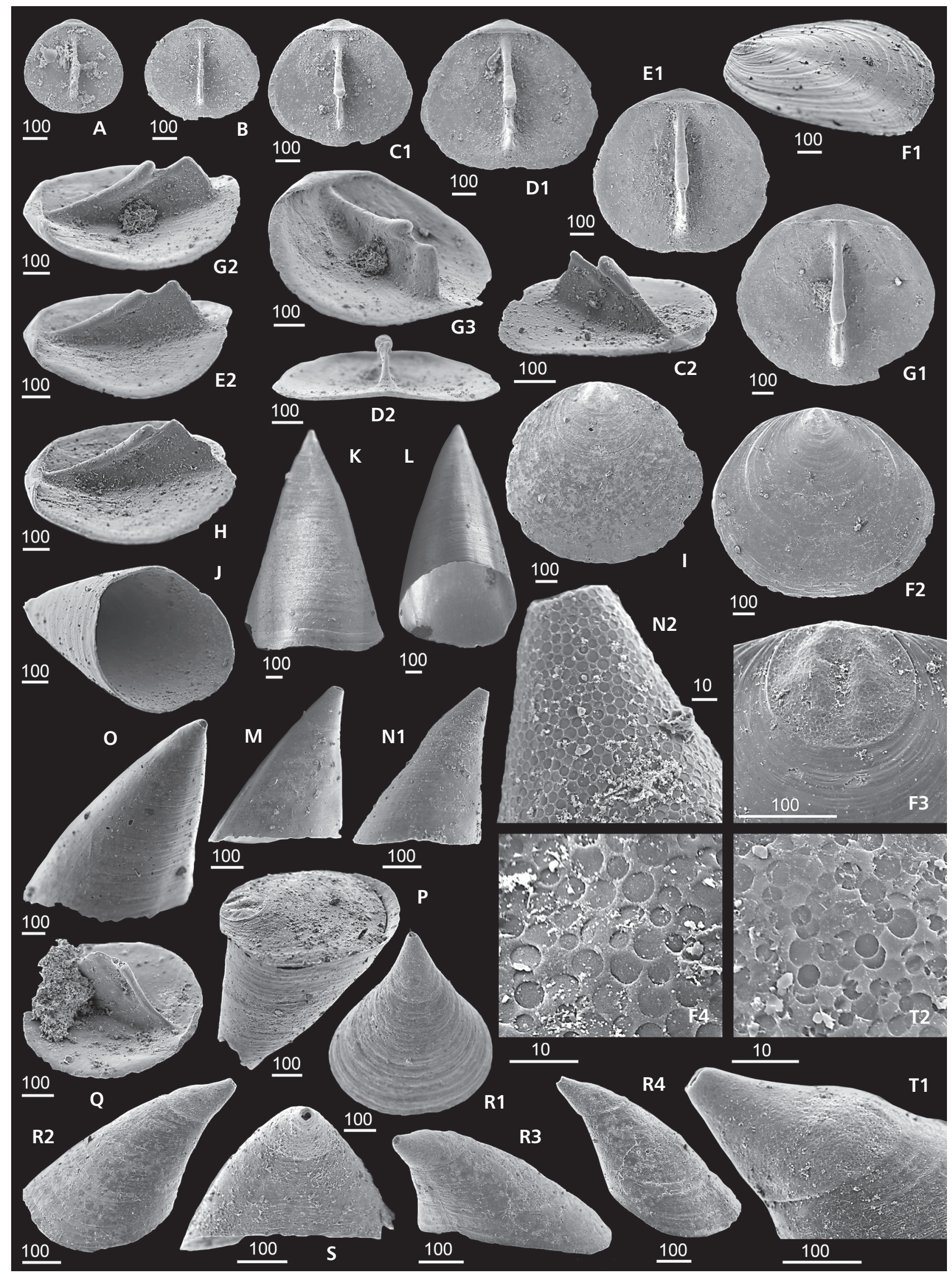


of the living animal. The holes of Orbaspina are also comparable in disposition and size to the holes penetrating shells of Late Cambrian siphonotretides Helmersenia and Gorchakovia (Williams et al. 2004).

Peripheral spines were extensions of the mantle forming hollow, thin, non-mineralized and perhaps branched spines along the shell periphery. Peripheral spines likely formed a sieve inhibiting the penetration of larger particles into the mantle cavity (Mergl et al. 2007). It seems ulikely that the peripheral ramified spines, exemplified by spines of Alichovia, could accomodate chitinous setae.

Following Popov et al. (2009) interpretation and comments, two different types of perforations in Orbaspina indicate their different origin. The first type of perforations accomodated sensoric setae protecting entire shell surface. The second type of perforations were continous, with hollow spines and form a sieve along shell periphery from budding generative epitheium.

Occurrence. - Ludfordian, upper part of the Kopanina Formation, Opsiconidion parephemerus-Kosagittella clara Community, samples K3, K4, K5, K10.

\section{Conclusions}

The analysis of the stratigraphical distribution of 15 organophosphatic brachiopod species based on more than 1300 determinable valves from the uppermost Neocucullograptus inexpectatus to lower Monograptus parultimus graptolite biozones (lower Ludfordian to the lowermost Přídolí) revealed a contrasting stratigraphical pattern (Figs 1,2). Numerical analyses of our newly gathered data have resulted in the establishment of three new organophosphatic brachiopod communities: the oldest Opsiconidion ephemerus Community, the Kosoidea fissurella Community, and the yougest Opsiconidion parephemerus-Kosagittella clara Community. The Opsiconidion ephemerus-Acrotretella siluriana Community, bearing 5 organophosphatic brachiopod species, is characterized by an abundance of micromorphous acrotretids and resembles the organophosphatic brachiopod association found in the older Cromus beaumonti Horizon (Mergl 2001a). At level of the Lau and Kozlowskii bioevents the Opsiconidion ephemerusAcrotretella siluriana Community was replaced by the monospecific Kosoidea fissurella Community (Fig. 1, Tab. 1) which is interpreted as an opportunistic community. The disappearance of the older community (as well as all micromorphous brachiopods) and appearance of the Kosoidea fissurella Community could be linked with a rapid cooling recorded in the same section (Lehnert et al. 2007b). The stratigraphical range of the Kosoidea fissurella Community fits well with the range of the highest values of the $\delta^{13} \mathrm{C}$ record and its LAD occurs in the limestone bed with the oldest occurrence of the the Ananaspis fecunda-Cyrtia postera Community (Figs 1, 3; Tab. 1). The Kosoidea fissurella Community was replaced by micromorphic organophosphatic brachiopods (the acrotretoids Opsiconidion and Acrotretella, a siphonotretid Orbaspina, and minute discinoids) belonging to the Opsiconidion parephemerus-Kosagittella clara Community which is restricted to upper part of the Ludfordian. It is noteworthy that the newly established organophosphatic brachiopod communities correlate well not only with the other faunal communities and lithological pattern but also with the chemostratigraphical zonation through the mid-Ludfordian carbon isotope excursion (see Fig. 3). In addition, the re-occurrence of some micromorphic brachiopod taxa (Fig. 1, Tab. 1) after recovery interval characterized by occurrence of large discinoids (Kosoidea fissurella) opens the question as to how much the Lau and Kozlowskii bioevents represent real global extinction events at least of organophosphatic brachiopods and whether their significance has not been overestimated. The adaptation of some Recent large discinoids to cold water regions and upwelling cold water systems may suggest that the Silurian extinction bioevents simply represent events when some taxa sensitive to cooling disappeared from the studied region and later, after the cooling period, returned back. Thus, their disappearance does not represent an extinction but only a change in the size of their ecospace.

The mid-Ludfordian carbon isotope excursion and associated extinction events represent a unique period in the Siluro-Devonian evolutionary history of the organophosphatic brachiopods of the Prague Basin. The micromorphic organophosphatic brachiopods had become fairly diversified already in the Llandovery

Figure 11. Orbaspina chlupaci Mergl, 2003, Kosov Quarry, samples K3 (A, B, G-K), K10 (C-F, L, M); A - exterior of incomplete ventral valve with small pedicle foramen (1) and its posteroventral view (2), JF195_23; B - exterior of dorsal valve (1), and detail of ornamentation (2), JF195_24; $\mathrm{C}$ - exterior of dorsal valve, JF195_17; D - exterior of dorsal valve ( $\overline{1})$, and its larval shell (2), JF195_18; E - exterior of dorsal valve in oblique (1), and dorsal (2) views, its larval shell (3), detail of ornamentation (4) showing large pores (5), and detail of large pore (6), JF195_19; F - exterior of incomplete ventral valve in oblique (1), and ventral views (2), and small hollow spines of its exterior (3), JF195_20; G - exterior of dorsal valve, JF195_25; H - interior of fragmental ventral valve, JF195_26; I - interior of fragmental ventral valve, JF195_27; J - dorsal pseudointerarea in ventral (1) and oblique views (2), JF195_28; K - interior of dorsal valve, JF195_29; L - interior of small dorsal valve in oblique view, JF195_21; $\mathrm{M}$ - interior of dorsal valve in ventral (1) and oblique (2) views, and its pseudointerarea in oblique view (3), JF195_22. Length of bars in $\mu$ m. 


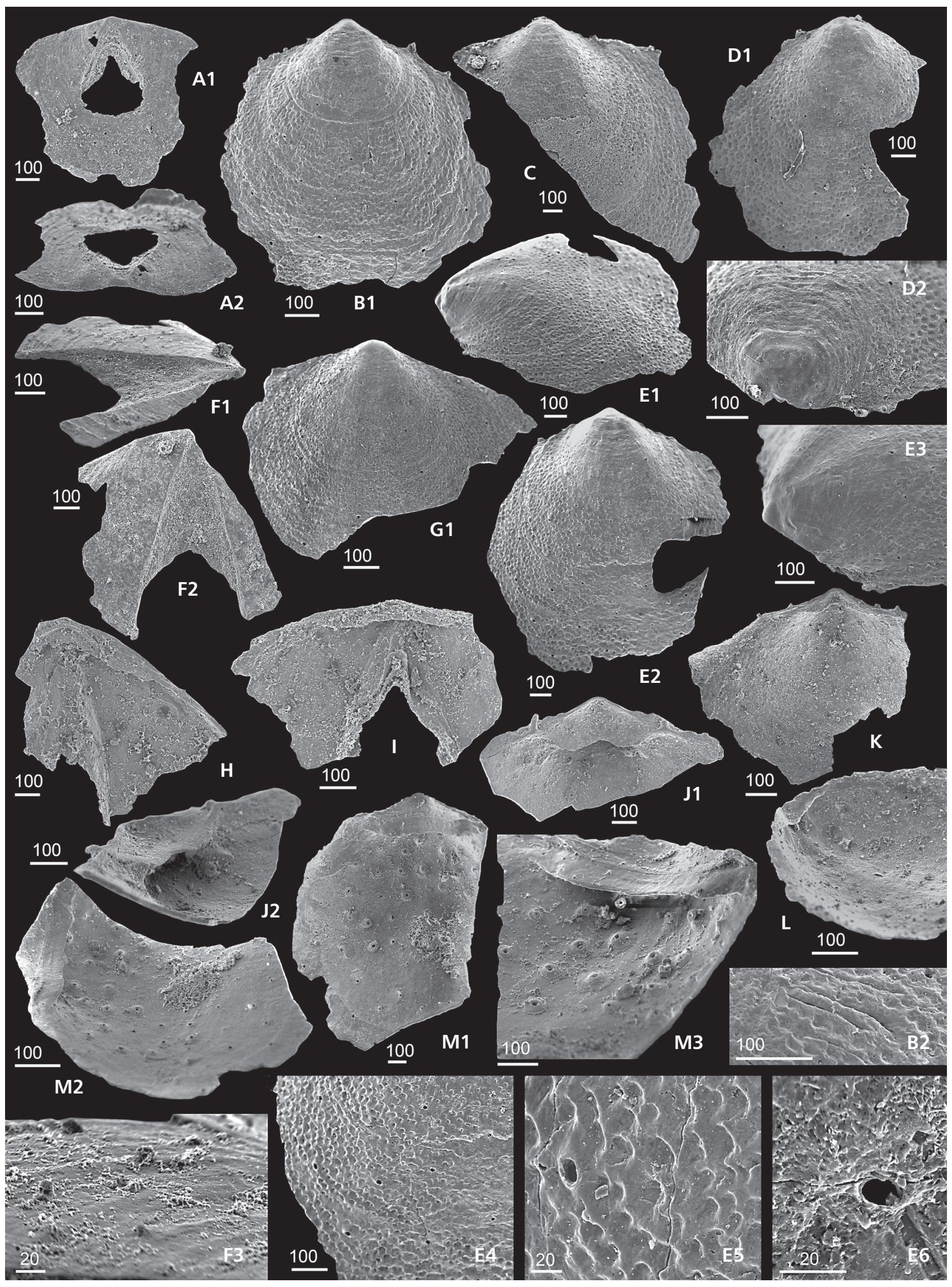


(Želkovice Formation), their diversification progressed in the Wenlock (Motol Formation) and early Ludlow (lower Kopanina Formation). Environmental changes linked with the mid-Ludfordian carbon isotope excursion interrupted this continuous evolutionary history. After a distinct break involving a recovery period after the Lau and Kozlowskii bioevents, from the late Ludfordian Ananaspis fecunda Horizon (upper Kopanina Formation) onwards the micromorphic organophosphatic brachiopod faunas again became an important part of faunal communities from the late Ludfordian to the Early Devonian.

\section{Acknowledgements}

This study was supported by two different grants: the research of MM and JF was supported by the Czech Science Foundation (GACR grant No. 17-18120S) and the research of MK and JF by an internal project (No. 339900) from the Czech Geological Survey. We thank David K. Loydell and Lars E. Holmer for their detail reviews, language corrections and constructive comments that significantly improved the manuscript. Finally, an excellent technical handling of Zuzana Tasáryová is also acknowledged.

\section{References}

Andrew, A.S., Hamilton, P.J., Mawson, R., Talent, J.A. \& Whitford, D.J. 1994. Isotopic correlation tools in the midPaleozoic and their relation to extinction events. APEA Journal 34, 268-77.

Baliński, A. \& Holmer, L.E. 1999. The Late Devonian trematid lingulate brachiopod Schizobolus from Poland. Acta Palaeontologica Polonica 44, 335-346.

Barrande, J. 1879. Systême silurien du centre de la Bohême. Iére partie. Recherches paléontologiques. Vol. 5. Classe des Mollusques. Ordre des Brachiopodes. 226 pp. Privately published, Prague \& Paris.

Barrick, J.E., Kleffner, M.A., Gibson, M.A., Peavey, F.N. \& Karlsson, H.R. 2010. The mid-Ludfordian Lau Event and Carbon Isotope Excursion (Ludlow, Silurian) in southern Laurentia - Preliminary Results. Bollettino della Società Paleontologica Italiana 49, 13-33.

Bassett, M.G. 1984. Life strategies of Silurian brachiopods. Special Papers in Palaeontology 32, 237-263.

Bassett, M.G., Popov, L.E., Aldridge, R.J., Gabbott, S.E. \& Theron, J.N. 2009. Brachiopoda from the Soom Shale Lagerstätte (upper Ordovician, South Africa). Journal of Paleontology 83, 614-623. DOI 10.1666/08-136.1

Biernat, G. \& Harper, D.A.T. 1999. A lingulate brachiopod Acrotretella: New data from Ordovician of Poland. Acta Palaeontologica Polonica 44, 83-92.

Botting, J.P. 2002. The role of pyroclastic volcanism in Ordovician diversification, 99-113. In CRAME, J.A. \& Owen, A.W. (eds). Palaeobiogeography and biodiversity change: the Ordovician and Mesozoic-Cenozoic radiations. Geological Society London, Special Publication 194.

BoučEK, B. 1934. Bemerkungen zur Stratigraphie des böhmischen Gotlandien und seinen Faziesverhaltnissen. Centralblatt für Mineralogie, Geologie und Palaeontologie, Abt. B 11, 477-494.

BouČEK, B. \& PřIBYL, A. 1955. O silurských ostrakodech a stratigrafii vrstev budňanských z nejbližšího okolí Kosova a Koledníku u Berouna. Sbornik Ústředního ústavu geologického, Oddil paleontologický 21, 577-662.

Boucot, A.J. 1975. Evolution and extinction rate controls. 427 pp. Elsevier, Balkema.

Boucot, A.J., Rowell, A.J., Racheboeuf, P., Pereira, E., Gonçalves de Melo, J.H. \& Peixoto de Siqueira, L. 2001. Position of the Malvinokaffric Realm's northern boundary (Early Devonian) based on newly discovered brachiopods from the Parecis Basin (Brazil). Journal of the Czech Geological Society 46, 109-120.

Brett, C.E., Ferretti, A., Histon, K. \& Schönlaub, H.P. 2009. Silurian sequence stratigraphy of the Carnic Alps, Austria. Palaeogeography, Palaeoclimatology, Palaeoecology 279, 1-28. DOI 10.1016/j.palaeo.2009.04.004

Brock, G.A., Engelbretsen, M.J. \& Dean-Jones, G. 1995. Acrotretoid brachiopods from the Devonian of Victoria and New South Wales. Memoirs of the Association of Australasian Palaeontologists 18, 105-120.

CAlner, M. 2008. Silurian global events - at the tipping point of climate change, 21-58. In Ashraf, M.T. (ed.) Mass extinctions. Springer-Verlag. Berlin \& Heidelberg.

CHerns, L. 1979. The environmental significance of Lingula in the Ludlow Series of the Welsh Borderland and Wales. Lethaia 12, 35-46. DOI 10.1111/j.1502-3931.1979.tb01240.x

Clarke, J.M. 1913. Fósseis Devonianos do Paraná. Monographias do Servico Geológico e Mineralógico do Brasil 1, 1-353.

Cocks, L.R.M. 1979. New acrotretacean brachiopods from the Palaeozoic of Britain and Austria. Palaeontology 22, 93-100.

Cocks, L.R.M. \& Popov, L. 2009. Generic homes for British linguloid brachiopods. Palaeontology 52, 349-367. DOI 10.1111/j.1475-4983.2009.00847.x

Cocks, L.R.M. \& Torsvik, T.H. 2002. Earth geography from 500 to 400 million years ago: a faunal and palaeomagnetic review. Journal of the Geological Society of London 159, 631-644. DOI 10.1144/0016-764901-118

Cooper, G.A. 1956. Chazyan and related brachiopods. Smithsonian Miscellaneous Collection 127, 1-1245.

Duméril, A.M.C. 1806. Zoologie analytique ou méthode naturelle de classification des animaux. xxiv +344 pp. Allais, Paris.

Ebbestad, J.O.R., FrÝda, J., Wagner, P., Horný, R., IsAKar, M., Stewart, S., Percival, I., Bertero, V., Rohr, D.M., Peel, J.S., Blodgett, R.B. \& Högström, A.E.S. 2013. Biogeography of Ordovician and Silurian gastropods, monoplacophorans and mimospirids, 191-212. In HARPer, D.A.T. \& SERVAIS, T. (eds) Early Palaeozoic Biogeography and Palaeogeography. Geological Society London, Memoir 38(1).

DOI 10.1144/M38.15

EMIG, C.C. 1997. Ecology of inarticulated brachiopods, 
473-495. In Williams, A., Brunton, C.H.C., Carlson, S. J. et al. (eds) Treatise on Invertebrate Paleontology, part $H$, Brachiopoda, Revised. Geological Society of America Inc. and The University of Kansas, Boulder, Lawrence.

Eriksson, M.J., Nilsson, E.K. \& Jeppsson, L. 2009. Vertebrate extinctions and reorganizations during the Late Silurian Lau Event. Geology 37, 739-742. DOI 10.1130/G25709A.1

Farkaš, J., Frýda, J. \& Holmden, C. 2016. Calcium isotope constraints on the marine carbon cycle and $\mathrm{CaCO}_{3}$ deposition during the late Silurian positive $\delta^{13} \mathrm{C}$ excursion. Earth and Planetary Science Letters 451, 31-40.

DOI 10.1016/j.eps1.2016.06.038

Farkaš, J., Frýda, J. \& Holmden, C. 2017. Corrigendum: Calcium isotope constraints on the marine carbon cycle and $\mathrm{CaCO}_{3}$ deposition during the late Silurian positive $\delta^{13} \mathrm{C}$ excursion. Earth and Planetary Science Letters 469, 170-171. DOI 10.1016/j.eps1.2017.04.013

FrÝdA, J. \& FrÝdovÁ, B. 2017. First paired carbonate-carbon and organic carbon isotope records across the Ludfordian (late Silurian) suggest elevated $\mathrm{pCO}_{2}$ before the largest Phanerozoic carbon isotope anomaly. GSA Annual Meeting in Seattle, Washington, USA, Abstract ID\# 299437.

FrÝdA, J. \& MANDA, Š. 2013. A long-lasting steady period of isotopically heavy carbon in the late Silurian ocean: evolution of the $\delta^{13} \mathrm{C}$ record and its significance for an integrated $\delta^{13} \mathrm{C}$, graptolite and conodont stratigraphy. Bulletin of Geosciences 88(2), 463-482. DOI 10.3140/bull.geosci.1436

Gocke, M., Lehnert, O. \& FrÝda, J. 2013. Facies development and palynomorphs during the Lau Event (Late Silurian) in a non-tropical carbonate environment: shallow and deep water examples from the Barrandian Area (Czech Republic). Facies 59, 611-630. DOI 10.1007/s10347-012-0328-y

GraY, J.E. 1840. Synopsis of the contents of the British Museum, $42^{\text {th }}$ edition. 370 pp. British Museum, London.

HARPER, D.A.T. 1984. Brachiopods from the Upper Ardmillan succession (Ordovician) of the Girvan district, Scotland. Part 1. Palaeontographical Society Monograph 136, 1-78.

Havlíček, V. \& Mergl, M. 1988. Two new discinid genera (Brachiopoda) from the Silurian and Devonian of the Prague Basin, Czechoslovakia. Věstník Českého geologického ústavu 63, 169-172.

Havlíček, V. \& Štorch, P. 1990. Silurian brachiopods and benthic communities in the Prague Basin (Czechoslovakia). Rozpravy Ústredního ústavu geologického 48, 1-275.

Havlí́̌́eK, V. \& ŠTorch, P. 1999. Silurian and Lochkovian Communities of the Prague Basin (Barrandian area, Czechoslovakia), 200-228. In Boucot, A.J. \& LAwson, J.D. (eds) Final report, Project Ecostratigraphy. Paleocommunities: A case study from the Silurian and Lower Devonian. Cambridge University Press, Cambridge.

HavlíčEK, V. \& VANĚK, J. 1996. Brachiopods and trilobites in the Chýnice Limestone (Emsian) at Bubovice (Čeřinka hillside; Prague Basin). Palaeontologica Bohemiae 2, 1-16.

HavlíčeK, V., VAnĚK, J. \& FAtKa, O. 1994. Perunica microcontinent in the Ordovician (its position within the Mediterranean Province, series division, benthic and pelagic associations). Sborník geologických věd, Geologie 46, 23-56.

Hiller, N. 1993. A modern analogue for the Lower Ordovician
Obolus conglomerate of Estonia. Geological Magazine 130, 365-367. DOI 10.1017/S0016756800009912

Histon, K. 2012 The Silurian nautiloid-bearing strata of the Cellon Section (Carnic Alps, Austria): Color variation related to events. Palaeogeography, Palaeoclimatology, Palaeoecology 367-368, 231-255.

DOI 10.1016/j.palaeo.2012.10.012

Histon, K. \& Schönlaub, H.P. 1999. The Palaeozoic of the Southern Alps. Berichte der Geologisches Bundesanstalt 47, 6-30.

Holmer, L.E. 1986. Inarticulate brachiopods around the MiddleUpper Ordovician boundary in Västergötland. Geologiska Föreningens i Stockholm Förhandlingar 108, 97-126. DOI 10.1080/11035898609452633

Holmer, L.E. 1989. Middle Ordovician phosphatic inarticulate brachiopods from Västergötland and Dalarna, Sweden. Fossils and Strata 26, 1-172.

Holmer, L.E. \& Popov, L.E. 2000. Lingulata, 30-146. In Williams, A., Brunton, C.H.C. \& CARlson, S.J. et al. (eds) Treatise on Invertebrate Paleontology, part H, Brachiopoda, Revised, Volume 2. Geological Society of America Inc. and The University of Kansas, Boulder, Lawrence.

HorNÝ, R. 1955. Studie o vrstvách budňanských v západní části Barrandienu. Sborník Ústředního ústavu geologického, Oddíl geologický 21, 315-447.

Ireland, H.A. 1961. New phosphatic brachiopods from the Silurian of Oklahoma. Journal of Paleontology 35, 1137-1142.

JePPSSON, L. 1987. Lithological and conodont distributional evidence for episodes of anomalous oceanic conditions during the Silurian, 129-145. In Aldridge, R.J. (ed.) Palaeobiology of Conodonts. Ellis Horwood Ltd., Chichester.

Jeppsson, L., Talent, J.A., Mawson, R., Andrew, A., Corradini, C., Simpson, A.J., Wigforss-Lange, J \& Schönlaub, H.P. 2012. Late Ludfordian correlation and the Lau Event. In TALENT, J.A. (ed.) Earth and Life, International Year of Planet Earth. Springer Science 2012.

Jeppsson, L., Talent, J.A., Mawson, R., Simpson, A.J., Andrew, A., Calner, M.,Whitford, D., Trotter, J.A., Sandström, O. \& Caldon, H.J. 2007. High-resolution late Silurian correlations between Gotland, Sweden, and the Broken River region NE Australia: lithologies, conodonts and isotopes. Palaeogeography, Palaeoclimatology, Palaeoecology 245, 115-137. DOI 10.1016/j.palaeo.2006.02.032

Kaljo, D., Kilpli, T. \& Martma, T. 1997. Carbon isotope event markers through the Wenlock-Pridoli sequence at Ohesaare (Estonia) and Priekule (Latvia). Palaeogeography, Palaeoclimatology, Palaeoecology 132, 211-223. DOI 10.1016/S0031-0182(97)00065-5

Kaljo, D., Boucot, A.J., Corfield, R.M., Le Herisse, A., Koren', T.N., Kriz, J., Männik, P., Märss,T., Nestor, V., Shaver, R.H., Siveter, D.J. \& ViIra, V. 1996. Silurian bioevents, 173-224. In Walliser, O.H. (ed.) Global Events and Event Stratigraphy in the Phanerozoic. Springer, Berlin.

Kaljo, D., Grytsenko, V., Kallaste, T., Kitpli, T. \& Martma, T. 2014. Upper Silurian stratigraphy of Podolia revisited: carbon isotopes, bentonites and biostratigraphy. Geologiska Föreningens i Stockholm Förhandlingar 136, 136-141.

DOI 10.1080/11035897.2013.862850 
Kaljo, D., Grytsenko, V., Martma, T. \& Mõtus, M.A. 2007. Three global carbon isotope shifts in the Silurian of Podolia (Ukraine): stratigraphical implications. Estonian Journal of Earth Sciences 56(4), 205-220.

DOI 10.3176/earth.2007.02

KING, W. 1846. Remarks on certain genera belonging to the class Palliobranchiata. Annals and Magazine of Natural History (Series 1) 18, 26-42.

KLyZA, J.S. 1997. The Tamworth Belt in the Tamworth-Attunga area: stratigraphy, structure, biochronologic and palaeoenvironmental analysis. 238 pp. Master thesis. Macquarie University, Sydney, Australia.

KozŁowski, W. \& Munnecke, A. 2010. Stable carbon isotope development and sea-level changes during the Late Ludlow (Silurian) of the Łysogóry region (Rzepin section, Holy Cross Mountains, Poland). Facies 56, 615-633.

DOI 10.1007/s10347-010-0220-6

KozŁowski, W. \& Sobień, K. 2012. Mid-Ludfordian coeval carbon isotope, natural gamma ray and magnetic susceptibility excursions in the Mielnik IG-1 borehole (Eastern Poland)Dustiness as a possible link between global climate and the Silurian carbon isotope record. Palaeogeography, Palaeoclimatology, Palaeoecology 339-341, 74-97. DOI 10.1016/j.palaeo.2012.04.024

KŘiž, J. 1987. Silur, 26-34. In ChlupÁč, I. (ed.) Vysvětlivky k základní geologické mapě ČSSR. 1:25 000, Králův Dvưr. Ústřední ústav geologický, Praha.

Křiž, J. 1991. The Silurian of the Prague Basin (Bohemia) tectonic, eustatic and volcanic controls on facies and faunal development. Special Papers in Palaeontology 44, 179-203.

Kř́žž, J. 1992. Silurian field excursions: Prague Basin (Barrandian), Bohemia. National Museum of Wales, Geological Series 13, 1-111.

KŘiž, J., 1998a. Silurian, 79-101. In Chlupáč, I., HAVLíčEK, V., KŘİ̌̌, J., Kunal, Z. \& ŠTorch, P. (eds) Paleozoic of the Barrandian (Cambrian to Devonian). Český geologický ústav, Praha.

Křiž, J. 1998b. Recurrent Silurian-Lowest Devonian cephalopod limestones of Gondwanan Europe and Perunica. New York State Museum Bulletin 491, 183-198.

KŘíž, J. 1999. Bivalvia dominated communities of Bohemian type from the Silurian and Lower Devonian carbonate facies, 225-248. In Boucot, A.J. \& Lawson, J.D. (eds) Final report, project Ecostratigraphy. Paleocommunities: A case study from the Silurian and Lower Devonian. Cambridge University Press, Cambridge.

KŘíž, J. 2008. A new bivalve community from lower Ludlow of the Prague Basin. Bulletin of Geosciences 83(3), 237-280. DOI 10.3140/bull.geosci.2008.03.237

Kunn, O. 1949. Lehrbuch der Paläozoologie. 326 pp. Schweizerbart, Stuttgart.

Kutorga, S.S. 1846. Ueber das silurische und devonische Schichten-System von Gatschina. Russisch-Kaiserliche Mineralogische Gesellschaft zu St. Petersbourg, Verhandlungen 1845-1846, 85-139.

Kutorga, S.S. 1848. Ueber die Brachiopoden-familie der Siphonotretaceae. Russisch-Kaiserliche Mineralogische Gesellschaft zu St. Petersbourg, Verhandlungen 1847, 250-286.
Lehnert, O., FrÝda, J., Buggisch,W. \& Manda, Š. 2003. A first report of the Ludlovian Lau event from the Prague Basin (Barrandian, Czech Republic). Serie Correlación Geológica 18, 139-144.

Lehnert, O., Eriksson, M.J., Calner, M., Joachimski, M. \& Buggisch, W. 2007b. Concurrent sedimentary and isotopic incications for global climatic cooling in the Late Silurian. Acta Palaeontologica Sinica 46, 249-255.

Lehnert, O., Frýda, J., Buggisch, W., Munnecke, A., Nützel, A., KŘIIŽ, J. \& MANDA, Š. 2007a. $\delta^{13} \mathrm{C}$ record across the Ludlow Lau Event: new data from mid palaeo-latitudes of northern peri-Gondwana (Prague Basin, Czech Republic). Palaeogeography, Palaeoclimatology, Palaeoecology 245, 227-244. DOI 10.1016/j.palaeo.2006.02.022

Loydell, D.K. 2007. Early Silurian positive $\delta^{13} \mathrm{C}$ excursions and their relationship to glaciations, sea-level changes and extinction events. Geological Journal 42(5), 531-546. DOI 10.1002/gj.1090

Loydell, D.K. \& FrÝDA, J. 2011. At what stratigraphical level is the mid Ludfordian (Ludlow, Silurian) positive carbon isotope excursion in the type Ludlow area, Shropshire, England? Bulletin of Geosciences 86, 197-208.

DOI 10.3140/bull.geosci.1257

Ludvigsen, R. 1974. A new Devonian acrotretid (Brachiopoda, Inarticulata) with unique protegular ultrastructure. Neues Jahrbuch für Geologie und Paläontologie, Monatshefte 3, 133-148.

MANDA, Š. 2008. Palaeoecology and palaeogeographic relations of the Silurian phragmoceratids (Nautiloidea, Cephalopoda) of the Prague Basin (Bohemia). Bulletin of Geosciences 83, 39-62. DOI 10.3140/bull.geosci.2008.01.039

MANDA, Š. \& KŘíž, J. 2006. Environmental and biotic changes of the subtropical isolated carbonate platforms during Kozlowskii and Lau events (Prague Basin, Silurian, Ludlow). Geologiska Föreningens $i$ Stockholm Förhandlingar 128, 161-168.

Manda, Š., Štorch, P., Slavík, L., Frýda, J., Kř́iž, J. \& TASÁRYOVÁ, Z. 2012. Graptolite, conodont and sedimentary record through the late Ludlow Kozlowskii Event (Silurian) in shale dominated succession of Bohemia. Geological Magazine 149, 507-531.

DOI 10.1017/S0016756811000847

Mendez-Alzola, R. 1938. Fósiles Devónicos del Uruguay. Instituto de Geología y Perforaciones, Boletín 24, 1-115.

Mendez-Alzola, R. \& Sprechmann, P. 1971. Algunas orbiculoideas devonicas de la Precordillera de San Juan, Rep. Argentina. Revista de la Asociació Geológica Argentina 24, 517-525.

Menke, C.T. 1828. Synopsis methodica molluscorum generum omnium et specierum earum quae in Museo Menkeano adservantur. 91pp. G. Uslar, Pyrmonti.

Mergl, M. 1982. Caenotreta (Inarticulata, Brachiopoda) in the Upper Silurian of Bohemia. Věstník Ústředního ústavu geologického 57, 115-116.

Mergl, M. 1999. Genus Paterula (Brachiopoda) in Ordovician-Silurian sequence of Central Bohemia. Věstnik Českého geologického ústavu 74, 347-361.

Mergl, M. 2001a. Lingulate brachiopods of the Silurian and 
Devonian of the Barrandian. Acta Musei nationalis Pragae, Series $B$ - Historia naturalis 57, 1-49.

Mergl, M. 2001b. Extinction of some lingulate brachiopod families: new stratigraphical data from Silurian and Devonian from Bohemia, 345-351. In BRunton, C.H.C., Cocks, L.R.M. \& Long, S. (eds) Brachiopods past and Present. Systematic Association Special Volume 63.

Mergl, M. 2003. Orbaspina chlupaci sp. nov., a new siphonotretid brachiopod from the Silurian of the Barrandian area, Bohemia. Bulletin of Geosciences 78, 419-421.

Mergl, M. 2009. Lingulate brachiopods from the Acanthopyge Limestone (Eifelian) of the Barrandian, Czech, Republic. Bulletin of Geoscinces 83, 281-298.

Mergl, M. 2010a. A review of Silurian discinoid brachiopods from Gotland, Sweden. Bulletin of Geosciences 85, 367-384. DOI 10.3140/bull.geosci.1176

Mergl, M. 2010b. Discinoid brachiopod life assemblages: Fossil and extant. Bulletin of Geosciences 85, 27-38.

DOI 10.3140/bull.geosci.1161

Mergl, M. 2012. Lingulate and craniate brachiopods from the top of the Králův Dvůr Formation (latest Katian) and their contribution to palaeogeography. Acta Musei Nationalis Pragae, Series B - Historia Naturalis 68, 35-46.

Mergl, M. \& Ferrová, L. 2009. Lingulate brachiopods from the Chýnice Limestone (upper Emsian, Barrandian; Czech Republic). Bulletin of Geosciences 84, 525-546. DOI 10.3140/bull.geosci.1143

Mergl, M. \& JimÉnez-SÁnchez, A. 2015. Lingulate brachiopods from the Suchomasty Limestone (upper Emsian) of the Barrandian, Czech Republic. Bulletin of Geosciences 90, 173-193. DOI 10.3140/bull.geosci.1533

Mergl, M. \& Massa, D. 2005. A new giant discinoid brachiopod from the Lower Devonian of Algeria. Acta Palaeontologia Polonica 50, 397-402.

Mergl, M. \& VodrážKovÁ, S. 2012. Emsian-Eifelian lingulate brachiopods from the Daleje-Třebotov Formation (Třebotov and Suchomasty limestones) and the Choteč Formation (Choteč and Acanthopyge limestones from the Prague Basin; the Czech Republic. Bulletin of Geoscinces 87, 315-332. DOI 10.3140/bull.geosci.1298

Mergl, M., Kraft, J. \& Kraft, P. 2007. Life habit and spatial distribution of siphonotretid brachiopods in the Lower Ordovician of the Prague Basin, Czech Republic. Earth and Environmental Transactions of the Royal Society of Edinburgh 98, 253-261. DOI 10.1017/S1755691007079856

Montecino, V. \& Lange, C.B. 2009. The Humboldt Current System: Ecosystem components and precesses, fisheries, and sediment studies. Progress in Oceanography 83, 65-79. DOI 10.1016/j.pocean.2009.07.041

Morris, J. 1849. Note on the genus Siphonotreta, with a description of a new species ( $S$. anglica). Annals and Magazine of Natural History, Series 2 \& 4, 315-321.

DOI 10.1080/03745486009494841

Morris, J. \& Sharpe, D. 1846. Description of eight species of brachiopod shells from the Paleozoic rocks of the Falkland Islands. Quarterly Journal of the Geological Society of London 2, 274-278.

DOI 10.1144/GSL.JGS.1846.002.01-02.47
Morzadec, P.M., Mergl, M., Villarroel, C., Janvier, P. \& Racheboeuf, P.R. 2015. Trilobites and inarticulate brachiopods from the Devonian Floresta Formation of Colombia: a review. Bulletin of Geosciences 90, 331-358.

DOI 10.3140/bull.geosci. 1515

Munnecke, A., Samtleben, C. \& Bickert, T. 2003. The Ireviken Event in the lower Silurian of Gotland, Sweden - relation to similar Palaeozoic and Proterozoic events. Palaeogeography, Palaeoclimatology, Palaeoecology 195, 99-124. DOI 10.1016/S0031-0182(03)00304-3

OrbignY, A. D'1847. Considérations zoologiques et géologiques sur les Brachiopodes ou Palliobranches. Comptes Rendus Hebdomodaires des Séances de l'Académie des Sciences 25, 193-195, 266-269.

Popov, L.E. 1981. Pervaia nakhodka mikroskopicheskikh bezzamkovykh brakhiopod semeistva Acrotretidae v Silure Estonii [The first record of microscopic inarticulate brachiopods of the family Acrotretidae from the Silurian of Estonia]. Eesti NSV Teaduste Akadeemia Toimetised (Keemia, Geoloogia) 30, 34-41.

Popov, L.E. 2000. Late Ordovician linguliformean microbrachiopods from north-central Kazakhstan. Alcheringa 24, 257-275. DOI 10.1080/03115510008619531

Popov, L.E., NõlvaK, J. \& Holmer, L.E. 1994. Late Ordovician lingulate brachiopods from Estonia. Palaeontology 37, 627-650.

Popov, L.E., Bassett, M.G., Holmer, L.E. \& Ghobadi Pour, M. 2009. Early ontogeny and soft tissue preservation in siphonotretide brachiopods: new data from the CambrianOrdovician of Iran. Gondwana Research 16, 151-161. DOI 10.1016/j.gr.2009.01.009

REED, F.R.C. 1925. Revision of the fauna of the Bokkeveld Beds. Annals of the South African Museum 22, 27-225.

Rowell, A.J. 1965. Inarticulata, 260-296. In Moore, R.C. (ed.) Treatise on Invertebrate Paleontology, Part H. Brachiopoda. The geological Society of America and The University of Kansas Press Boulder, Lawrence.

SAtTerfield, I.R. \& Thompson, T.L. 1969. Phosphatic inarticulate brachiopods from the Bainbridge Formation (Silurian) of Missouri and Illinois. Journal of Paleontology 43, 1042-1048.

Schuchert, C. 1893. Classification of the Brachiopoda. American Geologist 11, 141-167.

Sharpe, D. 1856. Description of Paleozoic Mollusca from South Africa. Transactions of the Geological Society of London, Series 2, 7.

Spiridonov, A., Stankevič, R., Gečas, T., Šilinskas, T., Brazauskas, A., Meidla, T., Ainsaar, L., Musteikis, P. \& RADZEVIČIUS, S. 2017. Integrated record of Ludlow (Upper Silurian) oceanic geobioevents - Coordination of changes in conodont, and brachiopod faunas, and stable isotopes. Gondwana Research 51, 272-288. DOI 10.1016/j.gr.2017.08.006

Stampfli, G.M., Raumer, J.F \& Borel, G.D. 2002. Paleozoic evolution of pre-Variscan terranes: From Gondwana to the Variscan collision. Geological Society of America Special Paper 364, 263-280.

Stricanne, L., Munnecke, A. \& Pross, J. 2006. Assessing mechanisms of environmental change: Palynological signals 
across the late Ludlow (Silurian) positive isotope excursion $\left(\delta^{13} \mathrm{C}, \delta^{18} \mathrm{O}\right)$ on Gotland, Sweden. Palaeogeography, Palaeoclimatology, Palaeoecology 230, 1-31.

DOI 10.1016/j.palaeo.2005.07.003

Sutton, M.D., Bassett, M.G. \& Cherns, L. 2000. Lingulate brachiopods from the Lower Ordovician of the Anglo-Welsh Basin. Part 2. Monograph of the Palaeontographical Society London 613, 61-114.

Talent, J.A., Mawson, R., Andrew, A.S., Hamilton, P.J. \& Whitford, D.J. 1993. Middle Palaeozoic extinction events: Faunal and isotopic data. Palaeogeography, Palaeoclimatology, Palaeoecology 104, 139-152.

DOI 10.1016/0031-0182(93)90126-4

TAPANILA, L. \& Holmer, L.E. 2006. Endosymbiosis in OrdovicianSilurian corals and stromatoporoids: A new lingulid and its trace from Eastern Canada. Journal of Paleontology 88, 750-759.

DOI 10.1666/0022-3360(2006)80[750:EIOCAS]2.0.CO;2

TAsÁryová, Z., JANOUŠEK, V. \& FrÝDA, J. 2018. Failed Silurian continental rifting at the NW margin of Gondwana - evidence from basaltic volcanism of the Prague Basin (TepláBarrandian Unit, Bohemian Massif). International Journal of Earth Sciences 107, 1231-1266.

DOI 10.1007/s00531-017-1530-5

Tonarová, P., Eriksson, M.E. \& Hints, O. 2012. A jawed polychaete fauna from the late Ludlow Kozlowskii event interval in the Prague Basin (Czech Republic). Bulletin of Geosciences 87, 713-732. DOI 10.3140/bull.geosci.1317

Ulrich, E.O. 1886. Descriptions of new Silurian and Devonian fossils. American Paleontology, Contributions 1, 3-35.

UrbaneK, A. 1993. Biotic crises in the history of Upper Silurian graptoloids: A palaeobiological model. Historical Biology 7, 29-50. DOI 10.1080/10292389309380442

Valentine, J.L. 2006a. Early Devonian brachiopods from the Cobar Supergroup, western New South Wales, 192-259. In Valentine, J.L. (ed.) Taxonomic assessment, biostratigraphy and faunal turnover of Silurian-early Devonian linguliformean brachiopods from New South Wales, Australia. $\mathrm{Ph}$.D. thesis. Macquarie University, Sydney, Australia.

VALENTINE, J.L. 2006b. A thorny problem revisited: a cladistic analysis of the Siphonotretida (Linguliformea, Brachiopoda), 261-342. In Valentine, J.L. (ed.) Taxonomic assessment, biostratigraphy and faunal turnover of Silurian-early Devonian linguliformean brachiopods from New South Wales, Australia. Ph.D. thesis. Macquarie University, Sydney, Australia.

Valentine, J. \& Brock, G.A. 2003. A new siphonotretid brachiopod from the Silurian of Central-Western New South Wales, Australia. Records of the Australian Museum 55, 231-244. DOI 10.3853/j.0067-1975.55.2003.1378

Valentine, J.L., Brock, G.A. \& Molloy, P.D. 2003. Linguliformean brachiopod faunal turnover across the Ireviken Event (Silurian) at Boree Creek, central-western
Now South Wales, Australia, 301-327. In Königshof, P. \& SCHIndler, E. (eds) Mid-Palaeozoic bio- and geodynamics: the north Gondwana-Laurasian interaction. Courier Forschungsinstitut Senckenberg 242.

Valentine, J.L., Cole, D. \& Simpson, A.J. 2006. Silurian linguliformean brachiopods and conodonts from the Cobra Formation, Southeastern New South Wales, Australia. Proceedings of the Linnean Society of New South Wales 127, 199-234.

VAnUXEM, L. 1842. Geology of New York. Part 3, comprising the survey of the third geological district, Natural History of New York (4, 3). 306 pp. D. Appleton \& Co., New York.

WaAgen, W. 1885. Salt Range fossils, I. Productus-Limestone fossils, Brachiopoda. Memoirs of the Geological Survey of India, Palaeontologica Indica (series 13) 4, 729-770.

Willard, B. 1928. The brachiopods of the Ottosee and Holston formations of Tennessee and Virginia. Bulletin of the Harvard Museum of Comparative Zoology 68, 255-292.

Williams, S.H. \& Lockley, M.G. 1983. Ordovician inarticulate brachiopods from graptolitic shales at Dob's Linn, Scotland; their morphology and significance. Journal of Paleontology 57, 391-400.

Williams, A., Holmer, L.E. \& Cusack, M. 2004. Chemicostructure of the organophosphatic shells of siphonotretide brachiopods. Palaeontology 47(5), 1313-1337. DOI 10.1111/j.0031-0239.2004.00404.x

Williams, A., Carlson, S.J., Brunton, C.H.C., Holmer, L. \& Popov, L.E. 1996. A supra-ordinal classification of the Brachiopoda. Philosophical Transactions of the Royal Society, Biological Sciences 355, 1171-1193. DOI 10.1098/rstb.1996.0101

Wright, A.D. \& McCleAn, A.E. 1991. Microbrachiopods and the end-Ordovician event. Historical Biology 5, 123-129. DOI 10.1080/10292389109380395

Wright, A.D. \& Nõlvak, J. 1997. Functional significance of the spines of the Ordovician lingulate brachiopod Acanthambonia. Palaeontology 40, 113-119.

Younes, H., Calner, M. \& Lehnert, O. 2016. The first continuous $\delta^{13} \mathrm{C}$ record across the Late Silurian Lau Event on Gotland, Sweden. Geologiska Föreningens i Stockholm Förhandlingar 1, 63-69.

ŽÁk, J. \& SlÁmA, J. 2018. How far did the Cadomian 'terranes' travel from Gondwana during early Palaeozoic? A critical reappraisal based on detrital zircon geochronology. International Geology Review 60, 319-338. DOI 10.1080/00206814.2017.1334599

Zettler, M.L., Bochert, R. \& Pollehne, F. 2009. Macrozoobenthos diversity on an oxygen minimum zone off northern Namibia. Marine Biology 156, 1949-1961. DOI 10.1007/s00227-009-1227-9

ZEZINA, O.N. 2008. Biogeography of the Recent Brachiopods. Paleontological Journal 42, 830-858.

DOI 10.1134/S0031030108080078 